Article

\title{
Sulfide Rb-Sr, Re-Os and In Situ S Isotopic Constraints on Two Mineralization Events at the Large Hongnipo Cu Deposit, SW China
}

\author{
Lujun Lin ${ }^{1}$, Renyi Chen ${ }^{2, *}$, Zhenshan Pang ${ }^{3,4, *}$, Hui Chen ${ }^{3,4}$, Jianling Xue ${ }^{3,4}$ \\ and Hongxiang Jia ${ }^{1}$ \\ 1 School of Earth Sciences and Resources, China University of Geosciences (Beijing), Beijing 100083, China; \\ llujun@cugb.edu.cn (L.L.); cugbjiahongxiang@126.com (H.J.) \\ 2 Institute of Mineral Resources, Chinese Academy of Geological Sciences, Beijing 100037, China \\ 3 Development and Research Center, China Geological Survey, Beijing 100037, China; \\ cgschenhui@163.com (H.C.); xuejianling369@126.com (J.X.) \\ 4 Technical Guidance Center for Mineral Resources Exploration, Ministry of Natural Resources of the People's \\ Republic of China, Beijing 100083, China \\ * Correspondence: crenyi@mail.cgs.gov.cn (R.C.); pzhenshan@mail.cgs.gov.cn (Z.P.)
}

Received: 6 March 2020; Accepted: 5 May 2020; Published: 7 May 2020

check for updates

\begin{abstract}
The Hongnipo deposit, a newly discovered large copper deposit in the Kangdian copper belt, SW China, is hosted in the Paleoproterozoic Hekou Group. This deposit contains $4200 \mathrm{Mt}$ of $\mathrm{Cu}$ ores, with an average grade of $1.42 \mathrm{wt}$ \% Cu. Orebodies occur mainly as stratiform, stratoid and lenticular forms. Mineralization consists predominantly of high grade vein-type ores and low grade laminated ores. Field relationships indicate vein-type mineralization crosscuts laminated mineralization and host rocks, indicating that there were at least two mineralization events during the formation of the deposit. Pyrite separates from the laminated ores yield a Rb-Sr isochron age of $1552 \pm 80 \mathrm{Ma}$, with a highly radiogenic initial ${ }^{87} \mathrm{Sr} /{ }^{86} \mathrm{Sr}$ ratio of $0.71214 \pm 0.00081$, indicating a major contribution from the ore-hosting rocks. Sulfides from the laminated ores have $\delta^{34} S$ values ranging from $-1.8 \%$ o to $11.4 \%$, with the vast majority in the range of $5.3 \%$ o to $11.4 \%$, suggesting the mixed derivation of sulfur from seawater sulfates and magmatic fluids. Chalcopyrite separates from the vein-type ores have a Re-Os isochron age of $794.8 \pm 7.9 \mathrm{Ma}$. The initial ${ }^{187} \mathrm{Os} /{ }^{188} \mathrm{Os}(2.8 \pm 1.2)$ and $\gamma_{\mathrm{Os}}$ $(+2202)$ values are slightly lower than the average values of continental crust, indicating a major metal source of the Hekou Group with minor mantle input. Sulfides from the vein-type ores have $\delta^{34} \mathrm{~S}$ values that range from $-10.3 \%$ o to $4.0 \%$ and cluster between $0 \%$ o to $2.2 \%$, which implies a significant contribution of magmatic-sourced sulfur with minor biogenic sulfur. Two major mineralization events have been identified. The $\mathrm{Rb}-\mathrm{Sr}$ age of the laminated ores likely records a VMS mineralization event at $\sim 1.6 \mathrm{Ga}$. The much younger Re-Os age is considered to represent the timing of an important mineralization event, which is likely related to the Neoproterozoic magmatism and/or metamorphism and represents a newly documented mineralization event to be targeted by exploration.
\end{abstract}

Keywords: in situ S isotope analysis; pyrite Rb-Sr dating; chalcopyrite Re-Os dating; Hongnipo Cu deposit; Kangdian copper belt

\section{Introduction}

The Kangdian copper belt, which extends for $\sim 300 \mathrm{~km}$ in the southwest of the Yangtze Block [1-4], is one of the most important iron-copper-gold production areas in China. The Lala copper ore field (Figure 1) is one of the most important and typical ore fields within this belt. Two large deposits (Luodang and Hongnipo, with $\mathrm{Cu}$ resources of $\sim 0.56$ and $\sim 0.64 \mathrm{Mt}$, respectively) and several medium-small 
deposits have been discovered in this ore field. Numerous studies of the Luodang deposit are available. These studies have reached an agreement that the host strata formed during the late Paleoproterozic, with zircon $\mathrm{U}-\mathrm{Pb}$ ages of $\sim 1.6$ to $1.7 \mathrm{Ga}$ [5-10].

The origin of the Luodang deposit has been discussed by many researchers, but it still remains controversial. Some authors argued that it is volcanogenic in origin, a model similar to VMS deposits, and mineralization is coeval with the host rock $(\sim 1.6-1.7 \mathrm{Ga}[11,12])$. Alternatively, the deposit was thought to be epigenetic in origin [2,13-18]. Li et al. [13], Sun et al. [14] and Greentree [15] reported the Re-Os model ages of molybdenite (928-1005 Ma), a Pb-Pb isochron age of sulfides ( $887 \mathrm{Ma})$, and Ar-Ar plateau ages of muscovite and biotite ( $848 \mathrm{Ma}$ and $860 \mathrm{Ma}$ ), respectively, proposing that it has formed by Neoproterozoic retrograde metamorphism. However, proper details and descriptions of the samples are lacking. Chen and Zhou $[2,16]$ reported a molybdenite Re-Os age of $1086 \mathrm{Ma}$ and a primary allanite U-Pb age of $1067 \mathrm{Ma}$. Zhu and Sun [17] and Song [18] reported chalcopyrite Re-Os isochron ages of $1290 \mathrm{Ma}$ and $1085 \mathrm{Ma}$, respectively. They suggested that the deposit formed in a single mineralization event related to regional Mesoproterozoic magmatism ( 1.1 to 1.3 Ga [19-21]), but was overprinted by post-ore hydrothermal events related to regional Neoproterozoic magmatism or metamorphism [22]. More recent work proposes the deposit formed by multiple episodes of mineralization events. Zhu et al. [23] reported four molybdenite Re-Os ages, ranging from 835 to $1306 \mathrm{Ma}$, and suggested that the deposit was formed by two major mineralization events at $\sim 1.3$ and $\sim 1.1 \mathrm{Ga}$. By contrast, Chen et al. [24] reported two in situ sulfide $\mathrm{Pb}-\mathrm{Pb}$ errorchron ages of $\sim 1.67$ and $\sim 1.1 \mathrm{Ga}$, and suggested that sulfides in this deposit have dominantly formed in these two periods. Additionally, abundant sulfur isotopic studies showed multi-source characteristics, including magmatic, seawater-derived sulfate and local bedrock strata [16,18,25].

The Hongnipo deposit, located in the Lala copper ore field, is a newly discovered large copper deposit, with an inferred $~ 4200 \mathrm{Mt}$ of ores, with an average grade of $1.42 \mathrm{wt} . \% \mathrm{Cu}$ [26]. Only a few studies have been conducted since its discovery. Zhu [27] summarized the geological setting, orebody characteristics and ore compositions of the deposit, and defined it as an IOCG (iron-oxide copper gold) deposit. Hu et al. [28] studied the metallogenic geological background, and indicated that complex tectonic evolution and frequent magma events provided favorable space and material conditions for the formation of the deposit. He described the geological characteristics of the deposit, and suggested that $\mathrm{Cu}$ mineralization is closely related to sodic volcanic rocks. Consequently, he proposed that the association of copper mineralization to sodic volcanics was an important prospecting tool. Zhang et al. [29] discussed the main ore-controlling factors, including lithology, structure, and alteration assemblages. They suggested that strata with sodic volcanic rocks, structural intersections, gabbros and relevant proximal wall-rock alterations (e.g., albitization, silicification, biotitization, chloritization) should be significant prospecting targets. Geochemical studies of ore-bearing volcanic rocks indicate that they have formed in a subduction-related extensional setting [30]. Sulfur isotope studies based on the types of ore-hosting rocks demonstrated that sulfur was dominantly derived from the mantle, and fluid inclusion microthermometry suggested a medium-high temperature and high salinity fluid was responsible for the formation of the deposit [30]. However, none of the studies described the mineralization styles or mineralization ages of this deposit. The sulfur isotopic compositions reported by Wang [30] were determined using conventional methodology, which may result in the potential mixing of polygenetic age populations of sulfides during mineral separation [31]. Precise age and sulfur isotope determinations of mineral deposits are vital for determining genetic type, constructing genetic and prospecting models, and guiding further mineral exploration [32].

In this study, we identified two mineralization styles on the basis of field observations. In order to constrain the timing of the two mineralization styles and determine the sources of ore-forming minerals, pyrite $\mathrm{Rb}-\mathrm{Sr}$ dating, chalcopyrite Re-Os dating and in situ sulfur isotopic analyses of sulfides from the Hongnipo deposit were carried out. We further discuss the implications of our study for the regional metallogeny of the Kangdian copper belt. 


\section{Regional Geology}

South China has a complex tectonic history, and consists of two major Precambrian continental blocks involving the Yangtze Block to the northwest and the Cathaysia Block to the southeast, separated by the Sibao orogen (Figure 1a) [33,34]. The Yangtze Block predominantly comprises Proterozoic strata and Neoproterozoic igneous rocks [35]. Archean basement rocks, the 2.90-2.95 Ga Kongling Complex, were only previously known to be exposed in the northern part of the Yangtze Block [36]. Recent studies of zircon xenocrysts in Paleozoic lamproites and detrital zircons in Proterozoic sedimentary rocks in the southwestern Yangtze Block indicate a higher proportion of Archean to Paleoproterozoic unexposed basement rocks beneath the Yangtze Block than previously thought [37-41]. The Archean rocks were metamorphosed to granulites at $\sim 2.03-1.97 \mathrm{Ga}$, and then were intruded by the $\sim 1.85 \mathrm{Ga}$ A-type granites and mafic dykes [42-47]. The Yangtze Block collided with the Cathaysia Block at 1.3-1.0 Ga, with the consolidation occurring at $\sim 1.0-0.85 \mathrm{Ga}$, resulting in widespread deformation, uplift, and regional metamorphism in these two blocks $[35,48,49]$.

The Kangdian copper belt, a major N-S-trending $\mathrm{Cu}$ metallogenic belt, is located in the southwestern part of the Yangtze Block (Figure 1a). The strata exposed here are predominantly Proterozoic volcanic-sedimentary successions that consist of arenaceous to argillaceous sedimentary rocks with minor volcanic rocks, and the unconformably overlying late Neoproterozoic (Sinian) to Cenozoic cover sequence, consisting of clastic, carbonate, and volcanic rocks [50]. The Proterozoic sequences, mainly controlled by the NS-trending Luzhijiang fault and a series of NNE-trending faults (Figure 1b), include the Paleoproterozoic Dongchuan, Hekou, and Dahongshan Groups with zircon U-Pb ages dominantly between $\sim 1.7 \mathrm{Ga}$ and $\sim 1.6 \mathrm{Ga}[6-8,10,39,51]$, and the Meso- to Neoproterozoic Huili, Kunyang, Julin, and Yanbian Groups, with zircon U-Pb age populations at 1.4-0.9 Ga [19,20,52-54]. As a result of the Neoproterozoic collisional orogenesis, termed the Sibao orogeny (860-815 Ma) [23], the Paleoproterozoic volcanic-sedimentary sequences underwent upper greenschist-lower amphibolite facies metamorphism [55], whereas lower greenschist facies metamorphism overprinted the Meso- to Neoproterozoic sequences $[55,56]$. Numerous Fe-Cu deposits are hosted within these meta-volcanic and meta-sedimentary rocks of the Paleoproterozoic Dahongshan, Hekou, and Dongchuan Groups in the Kangdian copper belt (Figure 1b) [1,16,22,23,57-59].

Mafic and felsic intrusions of Late Paleoproterozoic to Mesoproterozoic age ( 1.7-1.5 Ga) occur within the belt [39,59-63], show geochemical affinities of intra-plate magmatism, and are considered to have formed in a continental rift setting [7,39]. In addition, extensive tectonic-magmatic activity occurred at $\sim 960-740 \mathrm{Ma}$, which was almost simultaneous with regional metamorphism, and produced a variety of intrusive rocks comprising diabase, gabbros, diorites and granites in the Kangdian copper belt $[38,53,64-69]$. These Neoproterozoic plutons have been interpreted as either subduction-related $[53,64,66,67]$ or mantle plume-related $[65,68,69]$, of which the two largest granitic bodies are the Eshan pluton ( $819 \pm 8 \mathrm{Ma}$ [65]) and the Yuanmou pluton (746 $\pm 13 \mathrm{Ma}$ [64]). 


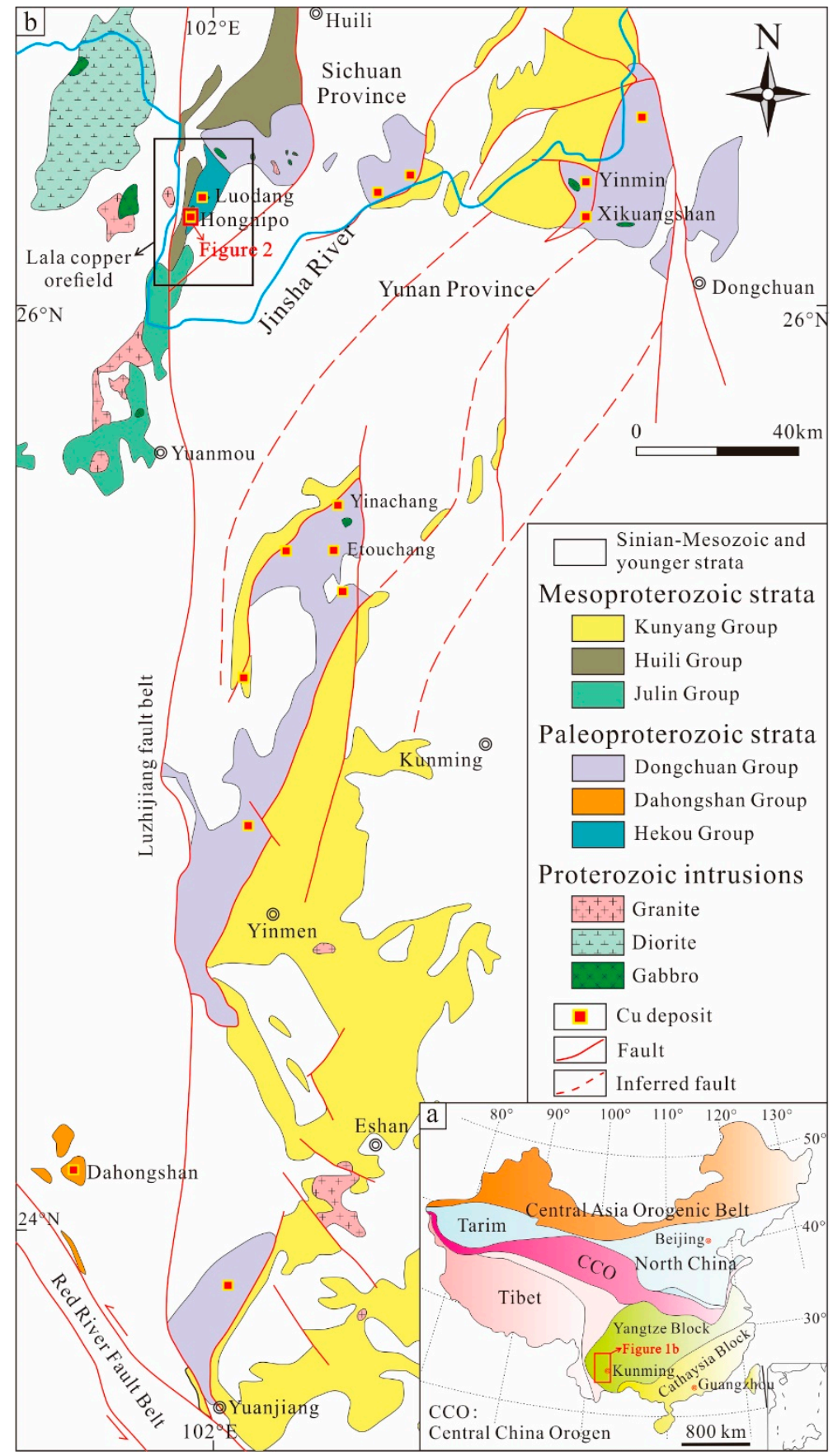

Figure 1. (a) Simplified geotectonic map showing the study area in the Yangtze Block (modified after [70]); (b) Regional geologic map showing Precambrian strata, intrusions and major Fe-Cu and $\mathrm{Cu}$ deposits in the Kangdian copper belt (modified after [16,59]).

\section{Deposit Geology}

The Hongnipo copper deposit, with central geographic coordinates of $101^{\circ} 57^{\prime} 00^{\prime \prime} \mathrm{E}$ and $26^{\circ} 11^{\prime} 30^{\prime \prime} \mathrm{N}$, is situated in the southwestern part of Huili County (Figure 1b). The exposed strata are the late Paleoproterozoic Luodang and Changchong Formations, Mesoproterozoic Heishan Formation, Triassic Baiguowan Formation, and overlying Quaternary (Figure 2). The Luodang Formation is sparsely distributed in the eastern margin of the deposit, and is composed predominantly of garnet-biotite schist, carbonaceous slate, quartz albitite, biotite-quartz schist, muscovite-quartz schist, two-mica quartz schist, and metatuff. Lenses of marble occur locally in this formation. The Changchong Formation, 
in conformable contact with the Luodang Formation, is exposed to the west and northeast of the deposit, and its lithological associations are similar to those of the Luodang Formation. The Heishan Formation, exposed in the northwest of the deposit, comprises carbonaceous slate, sericite phyllite, and marble. This formation is in fault contact with the Changchong Formation to the SE. The Baiguowan Formation, locally distributed in the southwest corner of the deposit, unconformably overlies the Changchong Formation. It mainly contains basal conglomerate, gritstone, shale, feldspar-quartz sandstone and siltstone. The Quaternary eluvial, alluvial and aqueoglacial sediments cover the entire central part of the deposit. The EW-striking Hongnipo synclinorium and NNE-striking faults $\left(\mathrm{F}_{13}, \mathrm{~F}_{27}, \mathrm{~F}_{30}\right)$ (Figure 2) are the major structures at Hongnipo.

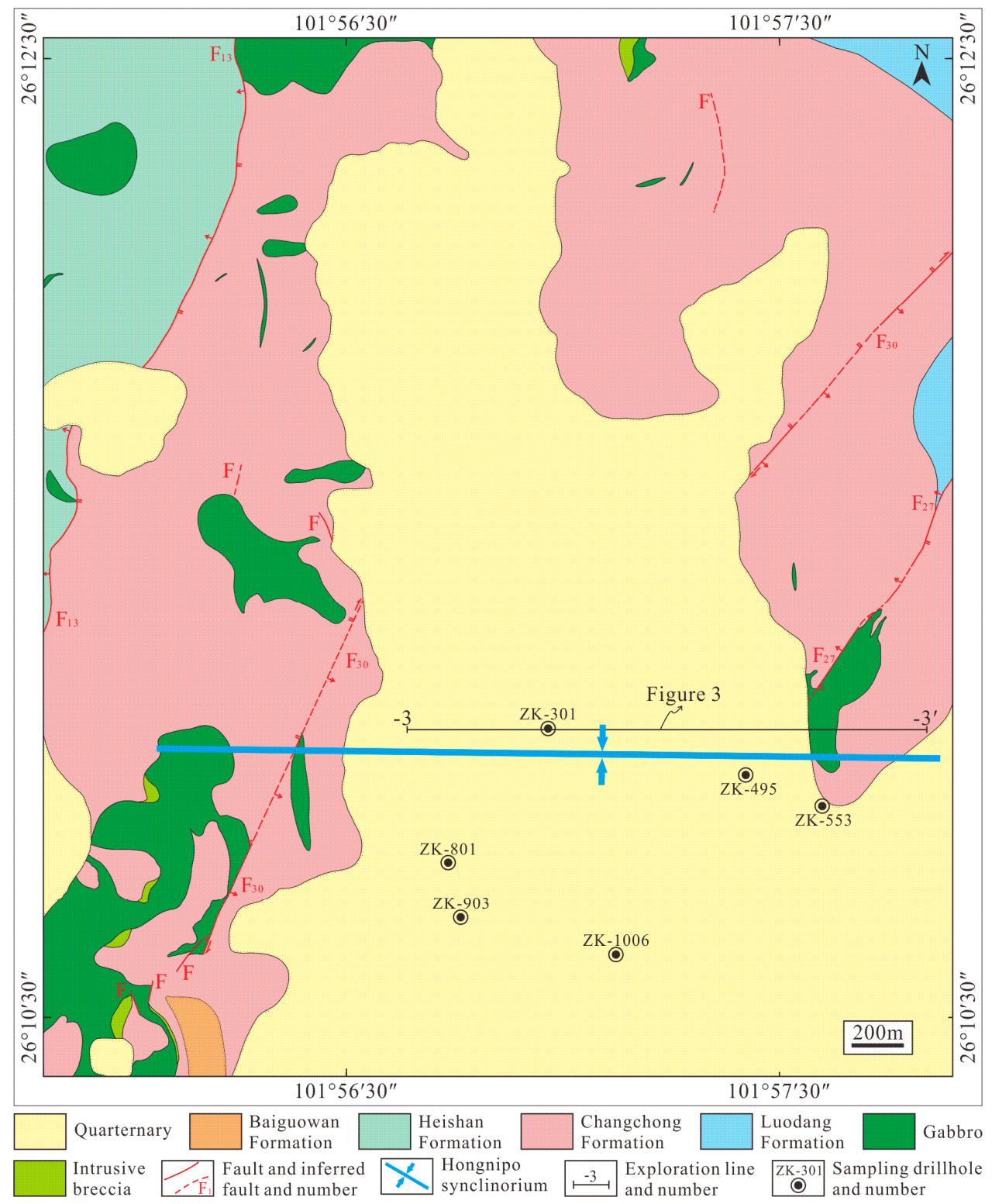

Figure 2. Geological sketch map of the Hongnipo Copper deposit (modified after [26]).

Extensive gabbro sills and dikes intrude the strata, but no other intrusive rocks have been identified. Intrusive breccias genetically related to the gabbro occur sporadically along boundaries between the strata and the intrusions (Figure 2). Additionally, abundant gabbro dikes and intrusive breccias also occur at various depths below the deposit (Figure 3). It is worth noting that fractures adjacent to the gabbro dikes, especially those in the hanging wall, commonly contain some mineralization. 


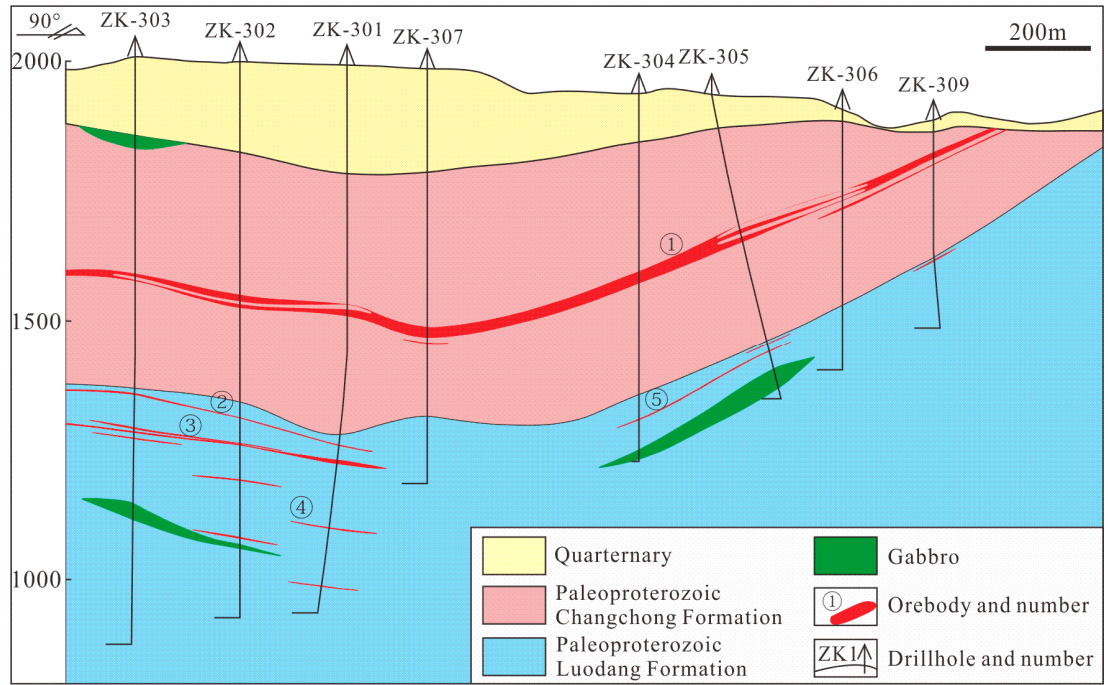

Figure 3. Geological cross-section of the number -3 exploration line of the Hongnipo copper deposit, showing the geometry of the orebodies and their relationships to the host rocks (modified after [26]).

Five orebodies occur as stratiform, stratoid and lenticular, and are hosted in the Changchong and Luodang Formations (Figure 3). These orebodies have an average copper grade of $1.42 \%$. The majority are strata bound, dipping $10^{\circ}-20^{\circ}$ to the southwest [26]. There are two ore varieties, namely, laminated and vein-type ores (Figure $4 \mathrm{a}-\mathrm{d}$ ), the latter of which is vastly more important in terms of metal reserves of the deposit. In the laminated ores, sulfides always occur parallel to the foliation (Figure 4a), indicating that they may have formed contemporaneously with the host rocks. Typical of the vein-type ores are sulfide-calcite \pm quartz veins that fill the fractures of the host rocks (Figure $4 \mathrm{~b}$ ) or overprint early laminated ores along the foliation (Figure 4c). It is common that vein-type mineralization crosscuts the laminated mineralization (Figure $4 \mathrm{~d}$ ), suggesting that economic $\mathrm{Cu}$ mineralization postdated the low-grade laminated mineralization.
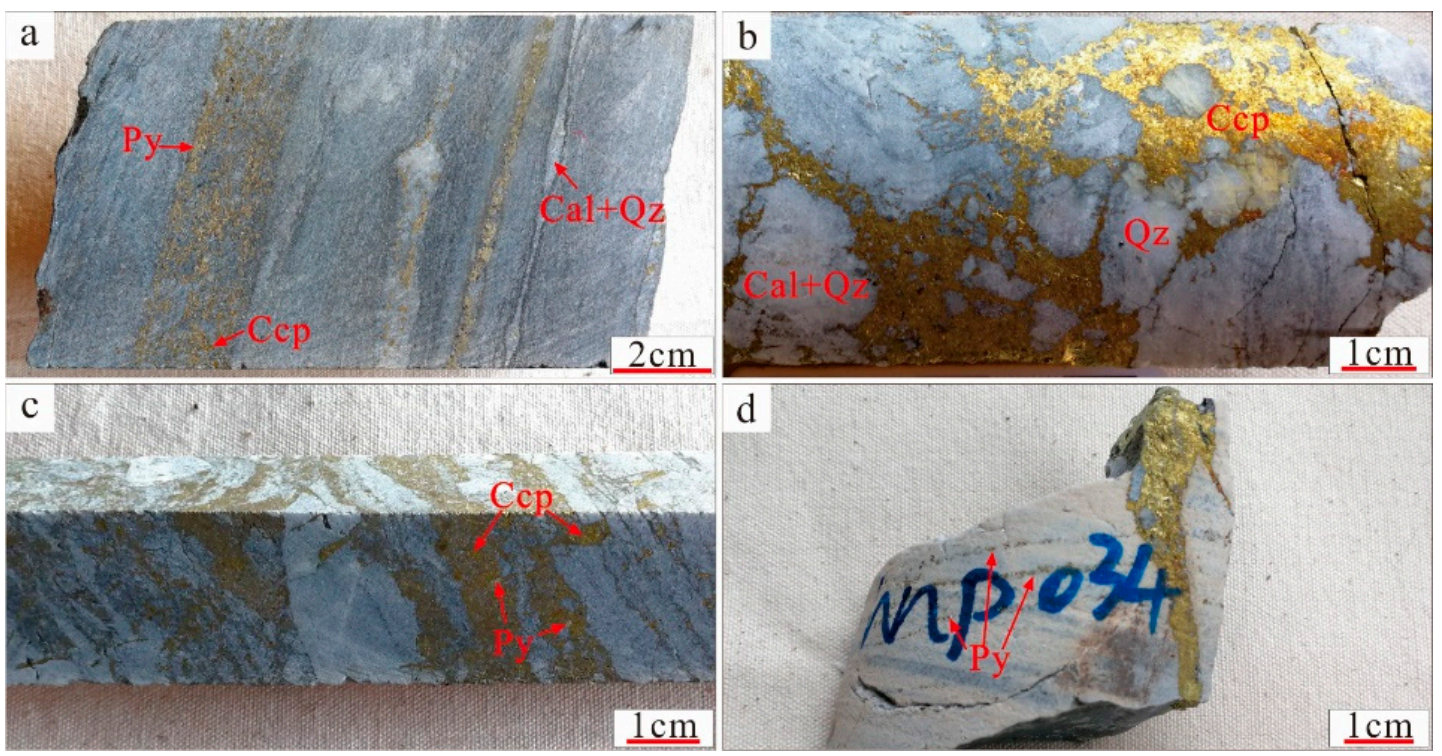

Figure 4. Photographs of representative ore hand specimens. (a) Laminated ore with sulfides parallel to the foliation; (b) vein-type ore showing quartz-calcite- sulfide veins filling the fractures of the host rock; (c) early laminated ore overprinted by late sulfide veins; (d) early laminated ore cut by late chalcopyrite vein. Mineral abbreviations: Py, pyrite; Ccp, chalcopyrite; Cal, calcite; Qz, quartz. 
Ore minerals in the laminated ores generally consist of abundant subhedral to anhedral pyrite and minor chalcopyrite (Figure 5a). Arsenopyrite, pyrrhotite and sphalerite are scarce (Figure 5b,c). Metasomatic texture and sieve texture of two stage pyrite are occasionally observed (Figure 5d). Ore mineral assemblages of vein-type ores are comprised of voluminous chalcopyrite and pyrite (Figure 5e-i), with minor bornite, pyrrhotite, hematite (Figure 5h,i), and magnetite. Gangue minerals of the two types of ores commonly comprise calcite, quartz, albite, chlorite, biotite, muscovite, and scarce titanite. In both types of ores, granular and metasomatic textures are most common (Figure 5). Exsolution texture of chalcopyrite within sphalerite is only observed in laminated ores (Figure 5c). Zoned pyrite is common in the vein-type ores (Figure $5 \mathrm{~g}$ ).
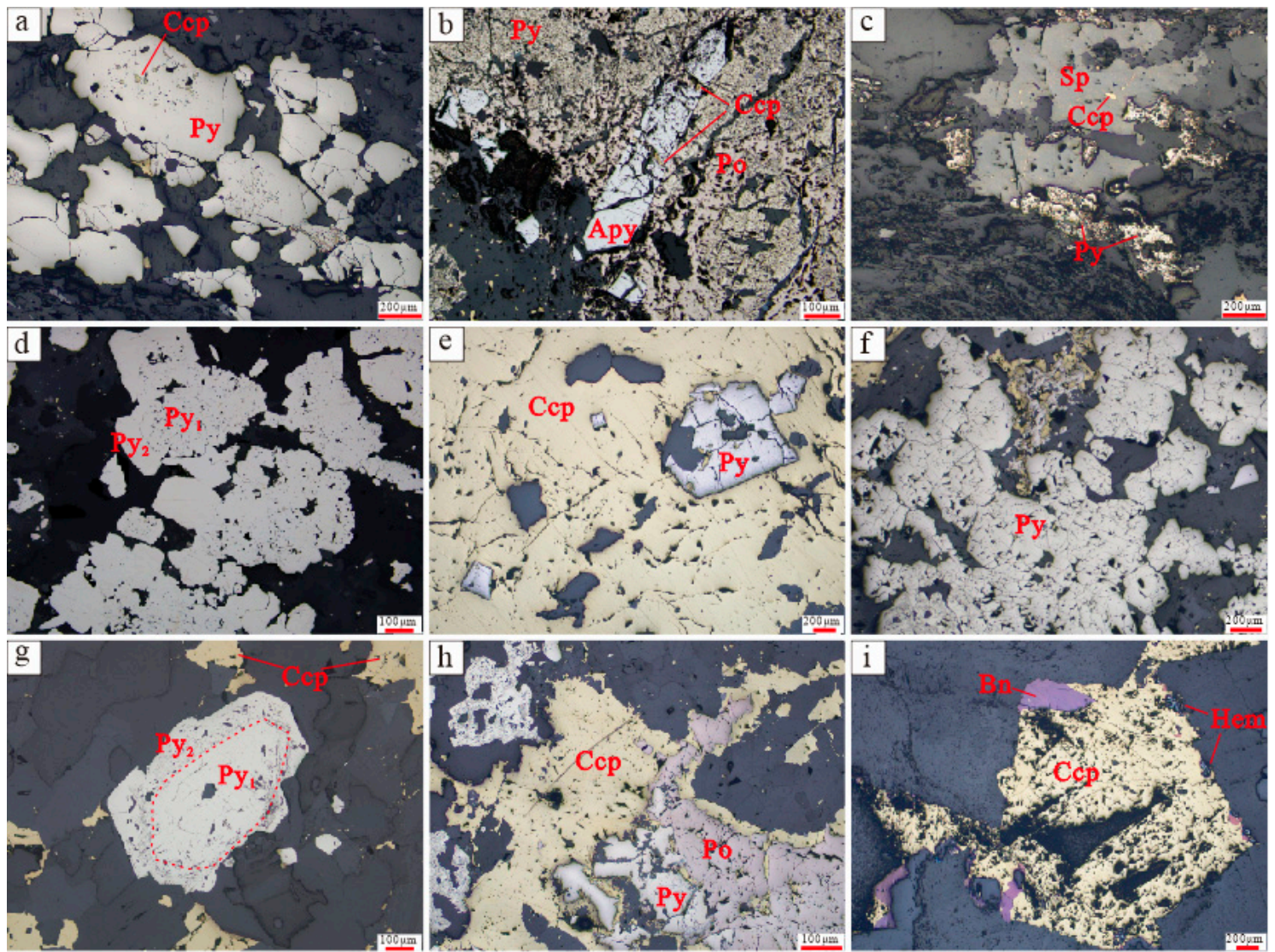

Figure 5. Photomicrographs showing the ore minerals of two types of ores; the laminated ore (Figure $5 \mathrm{a}-\mathrm{d}$ ) and the vein-type ore (Figure $5 \mathrm{e}-\mathrm{i}$ ). (a) Subhedral to anhedral pyrites, locally replaced by chalcopyrites; (b) arsenopyrite replaced and cut by other sulfides, indicating it was formed earliest; (c) chalcopyrite exsoluting from sphalerite; (d) late stage pyrite replacing early stage pyrite that include some of the matrix of the rock; (e) euhedral to subhedral pyrites enclosed or replaced by chalcopyrite; (f) granular pyrite; (g) zonal texture of pyrite, suggesting a later hydrothermal event; (h) pyrrhotite and pyrite replaced by chalcopyrite; (i) chalcopyrite partially replaced by bornite at the margin. Mineral abbreviations: Py, pyrite; Ccp, chalcopyrite; Apy, arsenopyrite; Po, pyrrhotite; Sp, sphalerite; Bn, bornite; Hem, hematite.

\section{Sampling and Analytical Methods}

\subsection{Sampling}

For the present study, 21 ore samples were taken from the drill cores provided by Geological Team 403 of Sichuan Geological and Mineral Exploration and Development Bureau. The sampling locations are shown in Figure 2 and Table 1. The ore type of these samples are also given in Table 1. Six relatively low-grade laminated ores (Hnp019, Hnp024, Hnp026, Hnp031, Hnp178 and Hnp181) were selected from 
the No.1 orebody for pyrite Rb-Sr dating. They are hosted in quartz albitite or muscovite-quartz schist. Among these samples, no obvious post-ore hydrothermal alteration was identified with the naked eye. The sulfides occur parallel to the foliation, showing a crude stratiform mineralogical partitioning. Petrographic observation revealed that mineral assemblages consist of abundant subhedral to anhedral pyrite, with minor chalcopyrite, quartz and calcite. In addition, it is worth mentioning that two stages of pyrite were observed in samples Hnp024 and Hnp026. In these samples, the early stage pyrite is locally enclosed by the late stage pyrite and/or show signs of metasomatism (Figure 5d). Six vein-type ores (Hnp484, Hnp487, Hnp488, Hnp490, Hnp493 and Hnp495) with high-grade Cu were selected from the No.1 orebody for chalcopyrite Re-Os geochronology. Irregular sulfide veins crosscut the wall rocks of marble, and are characterized by the mineral assemblage comprising dominant chalcopyrite, with minor pyrite, quartz and calcite. No later hydrothermal overprint was found in hand specimens and corresponding polished thin sections. Pure pyrite and chalcopyrite separates were handpicked under a binocular microscope after crushing, followed by magnetic and heavy liquid separation. These separates were then ground to about 200 mesh in an agate mortar.

Table 1. Locations of samples used in this study.

\begin{tabular}{|c|c|c|c|c|c|c|c|}
\hline Sample & Drill Hole & Depth (m) & Ore Type & Sample & Drill Hole & Depth (m) & Ore Type \\
\hline Hnp017 & \multirow{7}{*}{ ZK-301 } & 441 & \multirow{6}{*}{ Laminated } & Hnp483 & \multirow{7}{*}{ ZK-459 } & 256 & \multirow{7}{*}{ Vein-type } \\
\hline Hnp019 & & 443 & & Hnp484 & & 260 & \\
\hline Hnp022 & & 449 & & Hnp487 & & 266 & \\
\hline Hnp024 & & 450 & & Hnp488 & & 267 & \\
\hline Hnp026 & & 453 & & Hnp490 & & 278 & \\
\hline Hnp031 & & 458 & & Hnp493 & & 285 & \\
\hline Hnp053 & & 765 & Vein-type & Hnp495 & & 289 & \\
\hline Hnp178 & \multirow{2}{*}{ ZK-1006 } & 394 & \multirow{2}{*}{ Laminated } & Hnp499 & \multirow{4}{*}{ ZK-801 } & 519 & \multirow{4}{*}{ Vein-type } \\
\hline Hnp181 & & 399 & & Hnp503 & & 529 & \\
\hline Hnp223 & ZK-553 & 136 & Vein-type & Hnp504 & & 542 & \\
\hline Hnp287 & ZK-903 & 549 & Laminated & & & & \\
\hline
\end{tabular}

For sulfur isotope work, three representative laminated ores (Hnp017, Hnp022 and Hnp287) with minor laminated sulfides and six typical veined ores (Hnp053, Hnp223, Hnp483, Hnp499, Hnp503 and Hnp504) were made into polished thin sections. They share similar structural features, mineral associations and host rocks with those of samples used for Rb-Sr and Re-Os analyses.

\subsection{Analytical Methods}

The pyrite $\mathrm{Rb}-\mathrm{Sr}$ isotope analyses were carried out at the Analytical Laboratory of the Beijing Research Institute of Uranium Geology, Beijing, China, following the procedures and methods described in the literature [71]. Pyrite grains were washed ultrasonically in analysis-grade alcohol and ultrapure water. Subsequently, accurately weighed pyrite powder $(0.03-0.1 \mathrm{~g})$ was loaded into Teflon vial $(15 \mathrm{~mL})$, and then wetted with a little high purity water. Proper amounts of ${ }^{87} \mathrm{Rb}$ and ${ }^{84}$ Sr spikes were added into the vial, and then they were shaken to be uniform. After adding $3 \mathrm{~mL}$ hydrofluoric acid and 4 drops of perchloric acid and shaking the bottle, it was capped. Later, the bottle containing solution was heated on a hot plate with temperature around $120^{\circ} \mathrm{C}$ for $24 \mathrm{~h}$, until the sample dissolved completely. Hydrofluoric acid was expelled by heating it to $180{ }^{\circ} \mathrm{C}$, following the operations of removing the cap and evaporating the sample. The internal wall of the tubular bottle was washed twice with $2 \mathrm{~mL}$ of $6 \mathrm{~mol} / \mathrm{L}$ hydrochloric acid and then dried down at about $120{ }^{\circ} \mathrm{C}$. Then, $1 \mathrm{~mL}$ of $0.5 \mathrm{~mol} / \mathrm{L}$ hydrochloric acid was added into the tubular bottle to redissolve the sample, after which, the sample was transferred to plastic centrifuge tube. Finally, the supernatant used for the separation of rubidium and strontium was obtained through centrifugation for 6-10 min. The supernatant was then poured into the cation exchange column. A small amount of Milli-Q water was used to wash 
the corners of the column. Afterwards, $16 \mathrm{~mL}$ of $2 \mathrm{~mol} / \mathrm{L}$ hydrochloric acid was used to elute and remove impurities such as potassium, sodium and iron. Rubidium was desorbed into a quartz beaker $(10 \mathrm{~mL})$ by the use of $5 \mathrm{~mL}$ of $2 \mathrm{~mol} / \mathrm{L}$ hydrochloric acid. Moreover, $12 \mathrm{~mL}$ of $2 \mathrm{~mol} / \mathrm{L}$ hydrochloric acid together with $2 \mathrm{~mL}$ of $3 \mathrm{~mol} / \mathrm{L}$ hydrochloric acid was used to elute and remove ions such as calcium, magnesium and iron. Lastly, strontium was desorbed into a quartz beaker $(10 \mathrm{~mL})$ using $6 \mathrm{~mL}$ of $3 \mathrm{~mol} / \mathrm{L}$ hydrochloric acid. Pure rubidium and strontium were loaded on single rhenium filaments with $\mathrm{TaF}_{5}$ as activator. Rubidium and strontium isotopic compositions were then determined on a Phoenix TIMS instrument, in static multicollector mode. The internal precision of ${ }^{87} \mathrm{Sr} /{ }^{86} \mathrm{Sr}$ ratio is better than $0.002 \%$. Mass fractionation corrections in Sr isotopic analyses were done with ${ }^{86} \mathrm{Sr} /{ }^{88} \mathrm{Sr}$ value of 0.1194. During this study, the ${ }^{87} \mathrm{Sr} /{ }^{86} \mathrm{Sr}$ ratio for NBS $987 \mathrm{Sr}$ standard was $0.710250 \pm 7(2 \sigma)$. Both of the blanks for $\mathrm{Rb}$ and $\mathrm{Sr}$ are $0.2 \mathrm{ng}$ within the total procedure. Data regression for $\mathrm{Rb}$-Sr isochron age was done with the Isoplot software [72], using errors of $2 \%$ for ${ }^{87} \mathrm{Rb} /{ }^{86} \mathrm{Sr}$ ratios and the within-run measurement precision for ${ }^{87} \mathrm{Sr} /{ }^{86} \mathrm{Sr}$ values $(2 \sigma)$.

The chalcopyrite Re-Os isotope analyses were performed at the Re-Os Laboratory of the National Research Center of Geoanalysis, Chinese Academy of Geological Sciences, Beijing, China, utilizing isotope dilution-negative thermal ionization mass spectrometry (ID-NTIMS). Detailed analytical procedures used in this study are found in Du et al. [73,74]. A precisely weighed sample, together with a predetermined amount of mixed ${ }^{190}$ Os and ${ }^{185}$ Re spike was loaded into a Carius tube, and then digested by reverse aqua regia. The tube was sealed and then heated in an oven at $200{ }^{\circ} \mathrm{C}$ for $24 \mathrm{~h}$. After cooling, scratching, rewarming, and breaking off the tube's neck, the contents were poured into a distillation flask, and the residue was washed out into the flask with $40 \mathrm{~mL}$ of Milli-Q water. Osmium was separated and purified using distillation and microdistillation [75]. Rhenium was extracted from the residue by acetone in an $8 \mathrm{~mol} / \mathrm{L} \mathrm{NaOH}$ solution. The acetone phase was then transferred into a $100 \mathrm{~mL}$ beaker with $2 \mathrm{~mL}$ of Milli-Q water. The beaker was heated on a hot plate at $50{ }^{\circ} \mathrm{C}$ to expel acetone. When the acetone was exhausted, the heating temperature was increased to evaporate the solution to dryness. Afterwards, $0.8 \mathrm{~mol} / \mathrm{L} \mathrm{HNO}_{3}$ was added to neutralize and dissolve the residue. An appropriate amount of solution obtained from the previous step was added to an anion exchange column, which had been equilibrated with $0.8 \mathrm{~mol} / \mathrm{L} \mathrm{HNO}_{3}$. Then, $3 \mathrm{~mL}$ of $0.8 \mathrm{~mol} / \mathrm{L} \mathrm{HNO}_{3}, 2 \mathrm{~mL}$ of $1 \mathrm{~mol} / \mathrm{L} \mathrm{HCl}$ were added to elute impurities, and $1 \mathrm{~mL}$ of Milli-Q water was used to remove the $\mathrm{HCl}$. Lastly, $3 \mathrm{~mL}$ of $4 \mathrm{~mol} / \mathrm{L} \mathrm{HNO}_{3}$ was used to elute Re into a $7 \mathrm{~mL}$ Teflon vial. Re and Os concentrations and isotope compositions were determined using a Thermo Fisher Scientific Triton plus mass spectrometer, operating in negative ion detection mode [76]. Purified Re and Os were loaded onto platinum filaments with $\mathrm{Ba}(\mathrm{OH})_{2}$ as an ion emitter and measured as $\mathrm{ReO}_{4}^{-}$and $\mathrm{OsO}_{3}^{-}$, respectively. The signals of $\mathrm{Re}$ and Os were subsequently received by Faraday cups and secondary electron multiplier, respectively. Oxygen isotope interference was removed by means of a gradual spectral stripping method, according to the natural abundance of oxygen isotopes and statistical equal probability model [77]. The instrumental mass fractionation of Os was calibrated by normalizing the measured ${ }^{192} \mathrm{Os} /{ }^{188}$ Os ratio to 3.08271 [78]. The mass fractionation of Re was corrected using normal $\operatorname{Re}\left({ }^{185} \operatorname{Re} /{ }^{187} \operatorname{Re}=0.59738\right)$ as an external standard determined at the same temperature as the samples. Moreover, Re isotopic fractionation correction uncertainties of $0.1 \%$ were included in the calculations, even though the mass bias for $\mathrm{ReO}_{4}^{-}$ is small using NTIMS. On the basis of blank runs analyzed together with samples, the total procedural blanks for Re and Os were about 3 pg and $0.5 \mathrm{pg}$, respectively. Uncertainties for Re-Os isotopic dating were determined by error propagation of uncertainties in Re and Os mass spectrometer measurement and mass fractionation, bank abundances and isotopic compositions, spike calibrations, and weighing uncertainties of samples and spike. In addition, an in-house sulfide Re-Os isotope references JCBY from Jinchuan $\mathrm{Cu}-\mathrm{Ni}$ sulfide deposit was used for quality control of the whole procedure. Its results are identical with the recommended value within analytical uncertainty for Os isotopic compositions, as well as Re and Os concentrations.

Sulfides' in situ sulfur isotopic composition measurements were conducted on a Nu Plasma II MC-ICP-MS instruments at the State Key Laboratory of Geological Process and Mineral Resources 
(GPMR), China University of Geosciences (Wuhan). The detailed analytical procedure and conditions are given in Liu et al. [79]. In brief, the sulfides on polished thin sections were ablated by a Resonetics-S155 laser ablation system, with a laser energy fluence of $3 \mathrm{~J} / \mathrm{cm}^{2}$, a beam diameter of $33 \mu \mathrm{m}$, a repetition rate of $10 \mathrm{~Hz}$ and an ablation time of $40 \mathrm{~s}$. Ablated sulfide aerosols were carried by high purity helium and mixed with argon and minor nitrogen, before entering the plasma. Using the ${ }^{34} \mathrm{~S} /{ }^{32} \mathrm{~S}$ ratios of samples and the internal laboratory standard pyrite (WS-1) $\left(\delta^{34} S:+0.9 \%\right.$ ), the $\delta^{34} S$ values of sulfides from ore samples were obtained by using the sample-standard bracketing approach.

\section{Results}

\section{1. $R b$-Sr Isotopes}

The $\mathrm{Rb}-\mathrm{Sr}$ isotope data of six pyrite samples are listed in Table 2. They have variable contents of $\mathrm{Rb}(0.022$ to $0.446 \mathrm{ppm})$ and $\mathrm{Sr}(0.269$ to $1.74 \mathrm{ppm})$, with ${ }^{87} \mathrm{Rb} /{ }^{86} \mathrm{Sr}$ ratios from 0.1447 to 1.1854 . The scatter observed probably suggests the heterogeneity of the initial Sr isotopic compositions of the pyrite [80] or inclusions [81-83]. Both $\mathrm{Rb}$ and $\mathrm{Sr}$ are lithophile elements and are incompatible within pyrite [1]. Combined with the typical sieve texture (Figure 5f), the minerals within pyrite may be responsible for the variation.

Table 2. $\mathrm{Rb}-\mathrm{Sr}$ isotope data for pyrite from laminated ores in this study.

\begin{tabular}{|c|c|c|c|c|c|c|}
\hline Sample & $\mathrm{Rb}(\mathrm{ppm})$ & Sr (ppm) & ${ }^{87} \mathrm{Rb} /{ }^{86} \mathrm{Sr}$ & ${ }^{87} \mathrm{Sr} /{ }^{86} \mathrm{Sr}$ & $2 \sigma$ & $\left({ }^{87} \mathrm{Sr} /{ }^{86} \mathrm{Sr}\right)_{\mathrm{i}}{ }^{a}$ \\
\hline Hnp019 & 0.07 & 1.41 & 0.1447 & 0.715554 & 0.000013 & 0.712330 \\
\hline Hnp024 & 0.022 & 0.269 & 0.2374 & 0.715583 & 0.000019 & \\
\hline Hnp026 & 0.074 & 0.353 & 0.6095 & 0.716814 & 0.000019 & \\
\hline Hnp031 & 0.17 & 1.74 & 0.2819 & 0.718292 & 0.000021 & 0.712010 \\
\hline Hnp178 & 0.287 & 1.04 & 0.6771 & 0.727045 & 0.000019 & 0.711957 \\
\hline Hnp181 & 0.446 & 1.09 & 1.1854 & 0.738650 & 0.000011 & 0.712236 \\
\hline
\end{tabular}

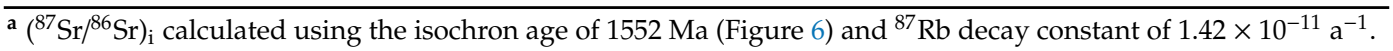

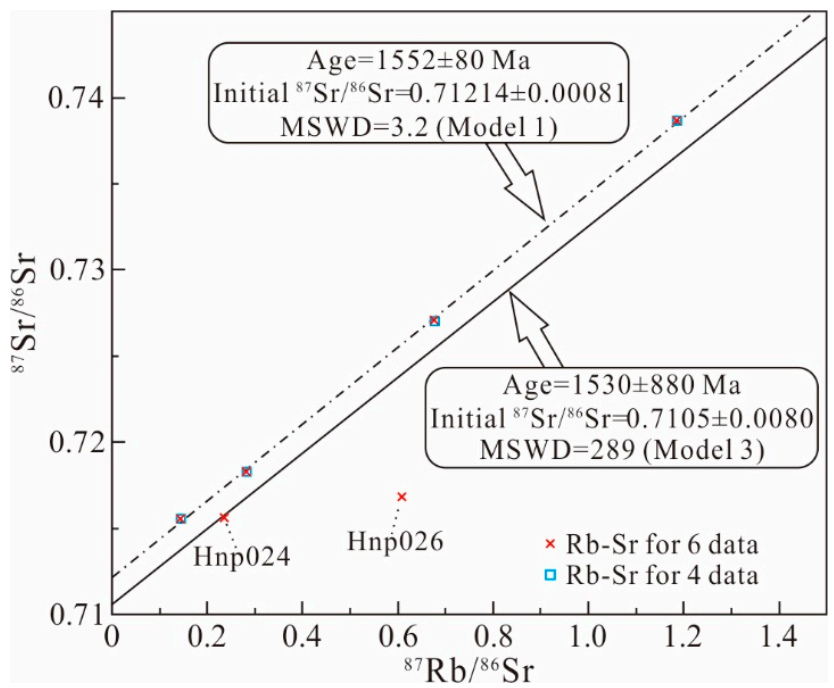

Figure 6. ${ }^{87} \mathrm{Rb} /{ }^{86} \mathrm{Sr}$ vs. ${ }^{87} \mathrm{Sr} /{ }^{86} \mathrm{Sr}$ isochron diagram of pyrite from laminated ores in the Hongnipo deposit.

Regression of all six Rb-Sr isotopic data gives a highly imprecise model 3 [72] date of $1530 \pm 880 \mathrm{Ma}$ (MSWD $=289$; Figure 6). Most of the scatter is attributable to Hnp024 and Hnp026. The isochron dating method requires that the samples have identical initial isotopic composition and the isotopic system remained closed after mineral crystallization [84]. In view of these requirements and our petrographic evidence (Figure 5d), samples Hnp024 and Hnp026 should be precluded for isochron age calculation. A best-fit line through the remaining four analyses defines a much more precise model 
1 age of $1552 \pm 80 \mathrm{Ma}$ (Figure 6), with an initial ${ }^{87} \mathrm{Sr} /{ }^{86} \mathrm{Sr}$ ratio of $0.71214 \pm 0.00081$ (MSWD = 3.2). Using the age of $1552 \mathrm{Ma}$, the calculated initial ${ }^{87} \mathrm{Sr} /{ }^{86} \mathrm{Sr}$ ratios for the remaining samples are 0.712330 , $0.712010,0.711957$, and 0.712236 (Table 1 ), with an average value of 0.712133 .

\subsection{Re-Os Isotopes}

Re and Os data of six chalcopyrite samples in which the blank corrections have been made are shown in Table 3. All samples contain low concentrations of Re and ${ }^{187} \mathrm{Os}$, with large concentration ranges of $0.7317-17.23 \mathrm{ppb}$ and $0.0083-0.1471 \mathrm{ppb}$, respectively. The abundances of common Os are low, but relatively uniform $(0.00329-0.00742 \mathrm{ppb})$. The ${ }^{187} \mathrm{Re} /{ }^{188} \mathrm{Os}$ ratios vary between 873.8 and 11225 , and the ${ }^{187} \mathrm{Os} /{ }^{188} \mathrm{Os}$ ratios range from 15.82 to 152.5 . The regression of $\operatorname{six}{ }^{187} \mathrm{Re} /{ }^{188} \mathrm{Os}-{ }^{187} \mathrm{Os} /{ }^{188} \mathrm{Os}$ data points with the corresponding uncertainty correlation value, yields a Re-Os model 3 [72] age of $874 \pm 310 \mathrm{Ma}$. The scatter of these data around the regression line is extremely large (MSWD $=954$; Figure 7a). A high MSWD value is indicative of the existence of geological scatter about the isochron in excess of the analytical uncertainty [85]. Most of the scatter is accounted for by samples Hnp487 and Hnp493, which deviate significantly from the regressive trend, compared with the remaining data (Figure 7a). Given the absence of petrographic evidence for post-ore hydrothermal overprint, the possible cause of deviation of the two samples is heterogeneity in their initial ${ }^{187} \mathrm{Os} /{ }^{188} \mathrm{Os}$ ratios, in comparison to the other four samples left. Considering the fundamental requirements for isochron dating [84], samples Hnp487 and Hnp493 are omitted. Regressing all the remaining data results in a model 1 (assumes that the scatter regarding to the linear regression only results from assigned uncertainty; [72]) Re-Os date of $794 \pm 12 \mathrm{Ma}\left(2 \sigma\right.$, initial ${ }^{187} \mathrm{Os} /{ }^{188} \mathrm{Os}=2.8 \pm 1.2$, MSWD = 2.9; Figure 7a). Using the calculation method given in Zhu and Sun [17], Selby et al. [86] and Li et al. [87], the abundance and uncertainty of radiogenic ${ }^{187} \mathrm{Os}\left({ }^{187} \mathrm{Os}^{\mathrm{r}}\right)$ of samples (Hnp484, Hnp488, Hnp490 and Hnp495) are derived from the corresponding total ${ }^{187}$ Os and error (Table 3). The ${ }^{187}$ Os budget is mainly composed of ${ }^{187} \mathrm{Os}^{\mathrm{r}}(81.95 \%-98.12 \%$; Table 3), which satisfies the characteristics of low-level highly radiogenic sulfide [87]. As a result, the ${ }^{187}$ Re versus ${ }^{188} \mathrm{Os}^{\mathrm{r}}$ data can be applied to determine a Re-Os date [88]. The ${ }^{187}$ Re versus ${ }^{188} \mathrm{Os}^{\mathrm{r}}$ data yield a model 1 four-point date of $794.8 \pm 7.9 \mathrm{Ma}$ $\left(2 \sigma\right.$, initial ${ }^{187} \mathrm{Os}=-0.0002 \pm 0.00075 \mathrm{ppb}, \mathrm{MSWD}=2.4$; Figure $\left.7 \mathrm{~b}\right)$, which is within the uncertainty of the ${ }^{187} \mathrm{Re} /{ }^{188}$ Os versus ${ }^{187} \mathrm{Os} /{ }^{188} \mathrm{Os}$ isochron age.
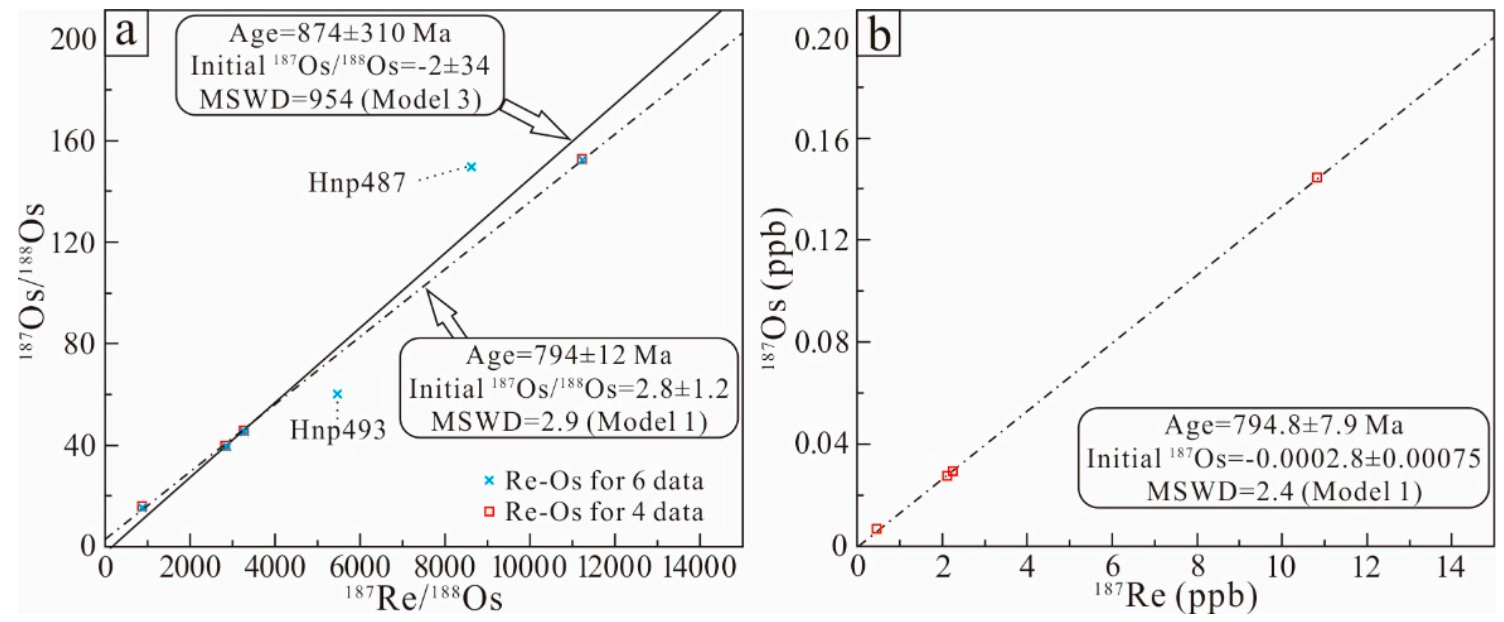

Figure 7. (a) ${ }^{187} \mathrm{Re} /{ }^{188} \mathrm{Os}$ vs. ${ }^{187} \mathrm{Os} /{ }^{188}$ Os plot and (b) ${ }^{187}$ Re vs. ${ }^{187} \mathrm{Os}$ plot of chalcopyrite from vein-type ores in the Hongnipo copper deposit.

Using the ${ }^{187} \operatorname{Re}$ (sample with ${ }^{187} \mathrm{Re} /{ }^{188}$ Os ratio exceeding 2800 ) and ${ }^{187} \mathrm{Os}^{\mathrm{r}}$ data, calculated model ages are $774 \pm 17 \mathrm{Ma}, 795 \pm 22 \mathrm{Ma}$ and $775 \pm 19 \mathrm{Ma}$, respectively (Table 3), and the weighted mean age is $779 \pm 26 \mathrm{Ma}(\mathrm{MSWD}=1.3)$. The relatively large uncertainties for model ages are attributed to the introduction of large errors caused by the blank correction for the extremely low level of Re and ${ }^{187} \mathrm{Os}$ 
in chalcopyrite [88]. Nevertheless, they can still provide additional information for mineralization ages. The ${ }^{187}$ Re versus ${ }^{187} \mathrm{Os}^{\mathrm{r}}$ isochron age (Figure $7 \mathrm{~b}$ ) is within uncertainty and in accordance with both the four-point ${ }^{187} \mathrm{Re} /{ }^{188}$ Os versus ${ }^{187} \mathrm{Os} /{ }^{188} \mathrm{Os}$ age (Figure $7 \mathrm{a}$ ) and the weighted mean age.

Furthermore, based on the values of initial ${ }^{187} \mathrm{Os} /{ }^{188}$ Os of 2.8 and ${ }^{187}$ Re versus ${ }^{187}$ Os isochron age of 794.8 Ma, an approximate $\gamma_{\text {Os }}$ value (+2202) is calculated using the formulas shown in Jiang et al. [89] and Walker et al. [90].

Table 3. Re-Os isotope data for chalcopyrite from vein-type ores in this study.

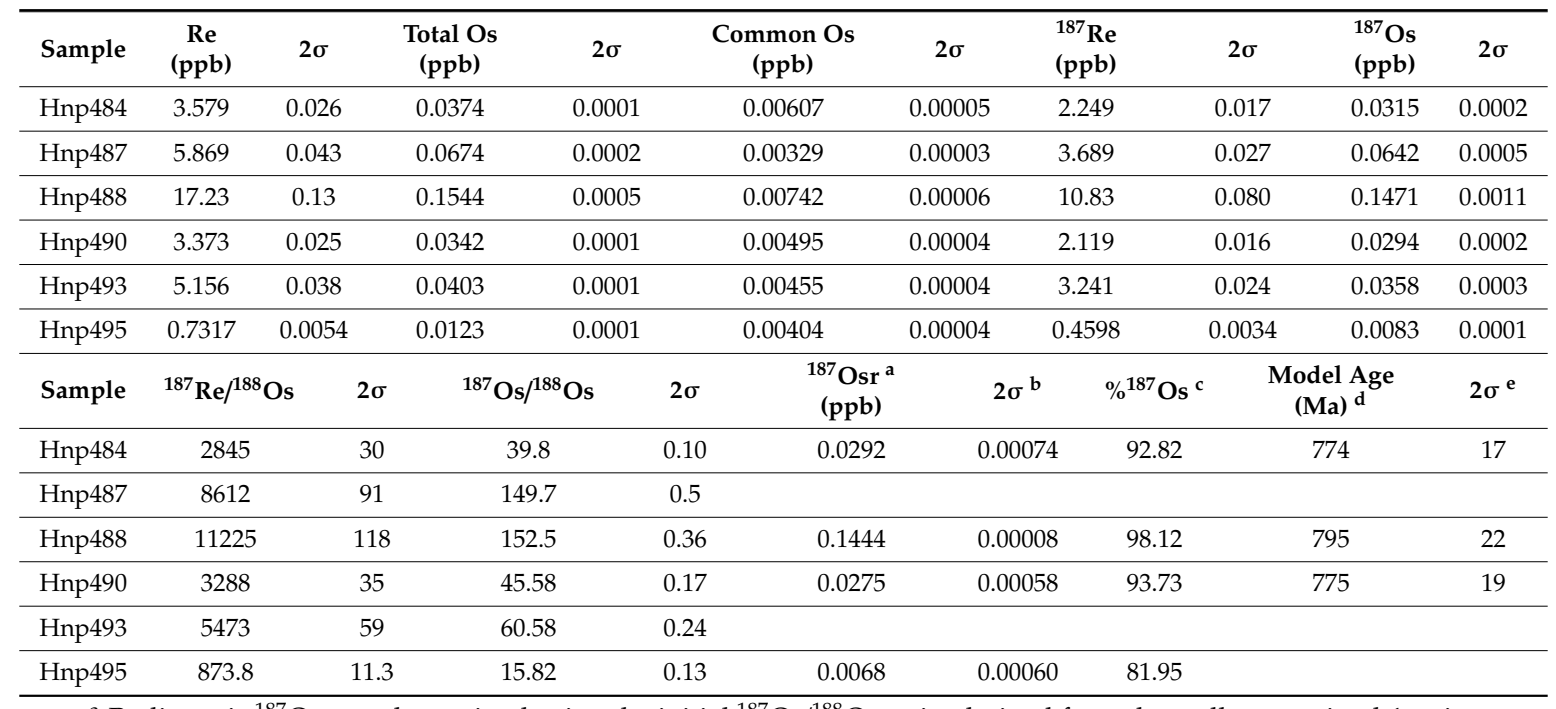

${ }^{\text {a }}$ Radiogenic ${ }^{187}$ Os was determined using the initial ${ }^{187} \mathrm{Os} /{ }^{188} \mathrm{Os}$ ratio, derived from the well-constrained 4-point isochron plot (Figure 7a). ${ }^{\mathrm{b}}$ Uncertainty of radiogenic ${ }^{187}$ Os was calculated on the basis of the errors of Common Os content and initial ${ }^{187} \mathrm{Os} /{ }^{188} \mathrm{Os}$ ratio. ${ }^{\mathrm{c}}$ Percentage of all measured ${ }^{187} \mathrm{Os}$ was determined from the radioactive decay of ${ }^{187}$ Re. ${ }^{d}$ Model ages were calculated only for samples with ${ }^{187} \mathrm{Re} /{ }^{188}$ Os ratios greater than 2800 , utilizing the ${ }^{187}$ Re decay constant of $1.666 \times 10^{-11} \mathrm{a}^{-1}$ with a relative uncertainty of $\pm 0.031 \%$ [91]. ${ }^{\mathrm{e}}$ Age uncertainty was determined based on error propagation of Re content, Os content, and ${ }^{187}$ Re decay constant errors.

\subsection{Sulfur Isotopes}

Sulfide isotopic data are listed in Table 4 and illustrated in Figure 8. Sulfides from the laminated ores have $\delta^{34} \mathrm{~S}$ values ranging from $-1.8 \%$ o to $11.4 \%$ o. Except for spot Hnp017-1 with a negative $\delta^{34} \mathrm{~S}$ value of $-1.8 \%$, both pyrite and chalcopyrite have high positive $\delta^{34} \mathrm{~S}$ values. The $\delta^{34} \mathrm{~S}$ values of sulfides from the vein-type ores range from $-10.3 \%$ o to $4.0 \%$, but mostly between $0 \%$ ond $2.2 \%$. Additionally, there are two samples, especially sample Hnp504, which have $\delta^{34} S$ values characterized by strong negative values (down to $-10.3 \%$ o). Overall, most of the $\delta^{34} \mathrm{~S}$ values of the sulfides from the laminated ores are much higher than those from vein-type ores (Figure 9).

Table 4. Sulfur isotope compositions (\%o) of sulfides analyzed in this study.

\begin{tabular}{ccccc}
\hline Ore Type & Sample & Spot & Mineral & $\delta^{34} \mathbf{S}$ \\
\hline \multirow{6}{*}{ Lamellar } & \multirow{3}{*}{ Hnp017 } & 1 & Pyrite & -1.8 \\
& & 2 & Chalcopyrite & 2.0 \\
\cline { 2 - 5 } & \multirow{3}{*}{ Hnp022 } & 1 & Pyrite & 6.5 \\
& & 2 & Chalcopyrite & 5.3 \\
& & 3 & Chalcopyrite & 5.4 \\
\cline { 3 - 5 } & & 1 & Pyrite & 10.3 \\
& & 2 & Pyrite & 10.4 \\
& & 3 & Pyrite & 8.6 \\
& & 4 & Pyrite & 11.4 \\
\hline
\end{tabular}


Table 4. Cont.

\begin{tabular}{|c|c|c|c|c|}
\hline Ore Type & Sample & Spot & Mineral & $\delta^{34} S$ \\
\hline \multirow{16}{*}{ Vein-type } & \multirow{2}{*}{ Hnp053 } & 1 & Pyrite & 4.0 \\
\hline & & 2 & Chalcopyrite & 1.1 \\
\hline & \multirow{4}{*}{ Hnp223 } & 1 & Pyrite & 1.6 \\
\hline & & 2 & Pyrite & 1.6 \\
\hline & & 3 & Chalcopyrite & 2.2 \\
\hline & & 4 & Chalcopyrite & 0.8 \\
\hline & \multirow{2}{*}{ Hnp483 } & 1 & Chalcopyrite & 1.3 \\
\hline & & 2 & Chalcopyrite & 1.8 \\
\hline & \multirow{3}{*}{ Hnp499 } & 1 & Pyrite & 0.3 \\
\hline & & 2 & Pyrite & 0 \\
\hline & & 3 & Chalcopyrite & -1.3 \\
\hline & \multirow{2}{*}{ Hnp503 } & 1 & Pyrite & -3.6 \\
\hline & & 2 & Chalcopyrite & -4.3 \\
\hline & \multirow{3}{*}{ Hnp504 } & 1 & Chalcopyrite & -9.6 \\
\hline & & 2 & Chalcopyrite & -9.4 \\
\hline & & 3 & Chalcopyrite & -10.3 \\
\hline
\end{tabular}

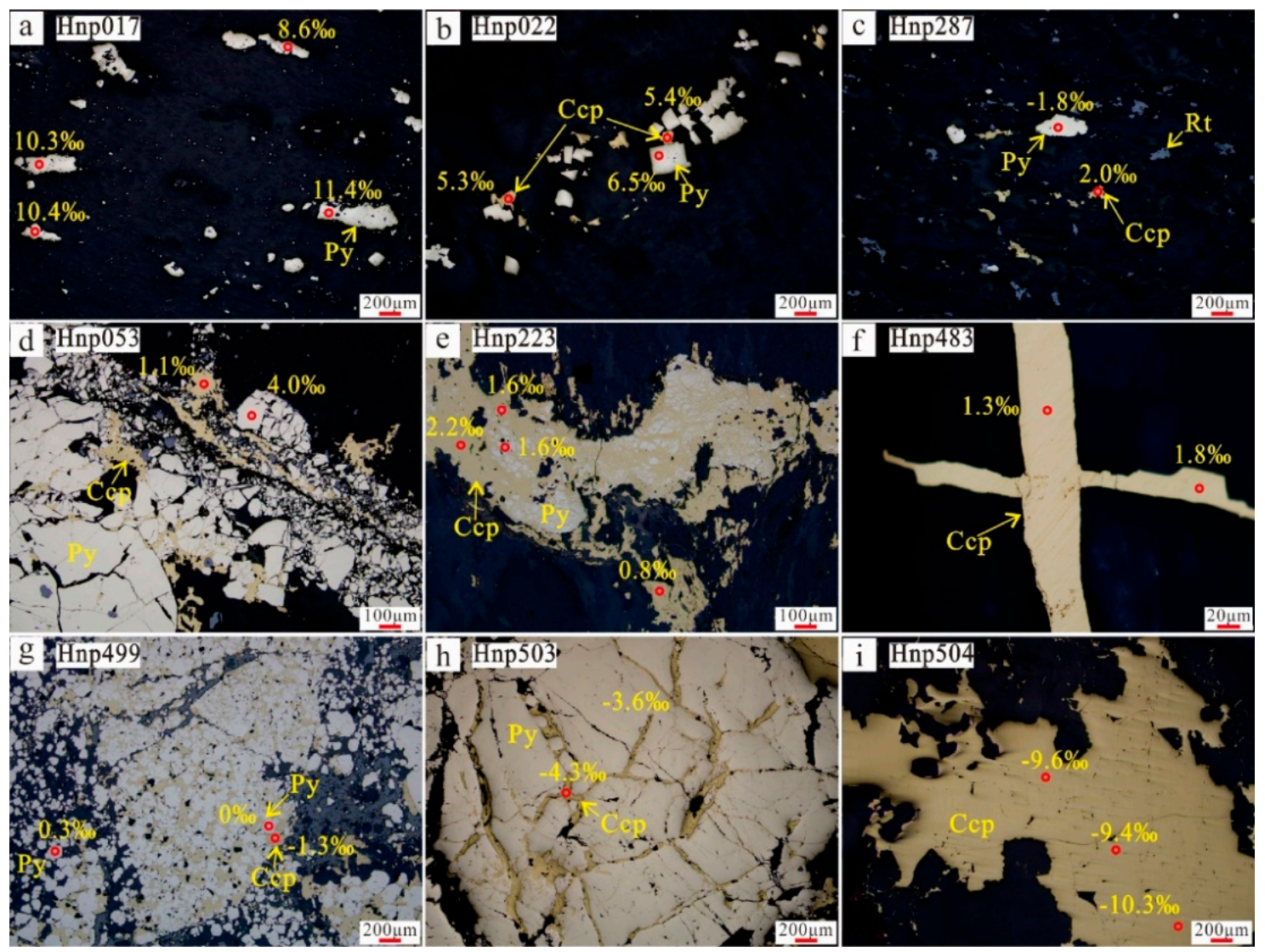

Figure 8. In situ $S$ isotope laser spot locations and corresponding $\delta^{34} S$ values of sulfides from the laminated ores $(\mathbf{a}-\mathbf{c})$ and vein-type ores $(\mathbf{d}-\mathbf{i})$ from the Hongnipo copper deposit. Mineral abbreviations: Py, pyrite; Ccp, chalcopyrite; Rt, rutile. 

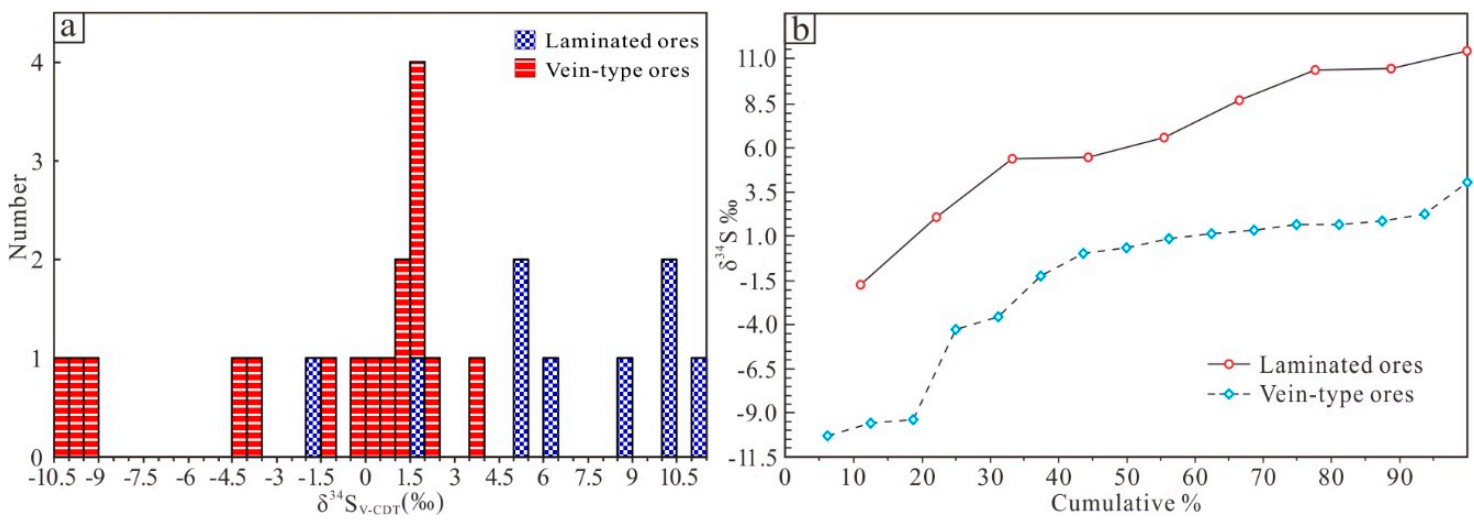

Figure 9. (a) Histogram and (b) CDF (cumulative distribution funtion) diagram of in situ sulfur isotope compositions of sulfide minerals from laminated and vein-type ores at the Hongnipo deposit.

\section{Discussion}

\subsection{Ages of Two Mineralization Events}

Field relationships show vein-type mineralization crosscut laminated mineralization (Figure 4d) at the Hongnipo deposit. Petrographic observation reveals that the percentage of chalcopyrite is significantly different in these two types of ores (Figures 5a-f and 8). This evidence suggests these two ore type might have formed from different metallogenic events.

For all isochron dating methods, including $\mathrm{Rb}-\mathrm{Sr}$, the prerequisites are that all samples have the same initial isotopic composition and the isotopic system remains closed after mineral crystallization [84]. Owing to the $\mathrm{Rb}$ and $\mathrm{Sr}$ budgets of pyrite are predominantly from silicate inclusions, the $\mathrm{Rb}-\mathrm{Sr}$ age of pyrite essentially represents the timing of the K-bearing minerals that cooled below the closure temperatures of the $\mathrm{Rb}-\mathrm{Sr}$ isotope system therein [1]. Although previous studies have shown that the Lala area has suffered from upper greenschist facies metamorphism [5], the pyrite Rb-Sr isotope age of $1552 \pm 80 \mathrm{Ma}$, with its large uncertainty, is consistent with the same stage pyrite $\mathrm{Pb}-\mathrm{Pb}$ age (1669 $\pm 110 \mathrm{Ma}$ [24]). This indicates that the $\mathrm{Rb}$-Sr isotope systematics of mineral inclusions within pyrite still remained closed. Additionally, the pyrite samples, which defined the well-constrained four-point regression line, were separated from the same ore type collected from the same orebody. Consequently, we suggest that the $\mathrm{Rb}-\mathrm{Sr}$ isochron age of $1552 \pm 80$ Ma likely represents the best estimate of the formation timing of the laminated ores.

In this study, we obtained a well-constrained four-point Re-Os chalcopyrite isochron age of $794.8 \pm 7.9 \mathrm{Ma}$ (Figure 7b) in this study. No deformation or hydrothermal overprint in chalcopyrite has been detected through field and microscopic observations. This suggests that the chalcopyrite Re-Os system has not been affected by post-ore tectonothermal events, and this age is considered to precisely record the timing of vein-type $\mathrm{Cu}$ mineralization. Apparently, it is significantly younger than the laminated mineralization. The field and textural relationships, coupled with our new geochemical data, indicate that at least two mineralizing events were involved in the formation of the Hongnipo deposit.

\subsection{Sources of Ore-Forming Materials}

\subsubsection{Laminated Ores}

The ${ }^{87} \mathrm{Sr} /{ }^{86} \mathrm{Sr}$ ratio is generally used to discriminate the sources of ore-forming fluids and materials. For example, Chen et al. [92] and Zhao et al. [93] managed to trace distinct fluids sources by comparing the $\mathrm{Sr}$ isotopic compositions of apatites with those of other reservoirs. The initial ${ }^{87} \mathrm{Sr} /{ }^{86} \mathrm{Sr}$ value $(\sim 0.712)$ at $\sim 1.6 \mathrm{Ga}$ is highly radiogenic, indicating a major contribution from crustal materials. The Paleoproterozoic host rocks with documented ${ }^{87} \mathrm{Sr} /{ }^{86} \mathrm{Sr}$ ratios from 0.711614 to 0.718937 at the time of the laminated mineralization [5], are likely candidates accounting for the radiogenic Sr of the 
laminated ores. This is in agreement with a previous $\mathrm{Pb}$ isotope study of pyrite from this ore type, which demonstrated that ore-forming materials were sourced from the Hekou Group [11].

The heavy sulfur isotope characteristics (up to $11.4 \%$ ) for the laminated sulfides are also observed in other deposits of the Kangdian copper belt; for instance, the Dongchuan, Etouchang and Tangdan deposits [59,94]. In addition, such sulfur isotope compositions are comparable to those of sulfides in Emmie Bluff (2.6\%o-12.5\%o, most values larger than 5.2\%o [95]) and Mount Gunson (7.1\%o-11.7\%o [96]), both of which are located in the Olympic Dam District of South Australia. Bastrakov et al. [95] proposed evaporates, calcareous host rocks or seawater to be the source of sulfur in the Olympic Dam district. Zhao et al. [94] and Huang et al. [97] suggested that the marine evaporates contributed sulfur during precipitation of sulfides in the Tangdan deposit. Considering the volcanism, marine paleogeographic environment [98] and the $\delta^{34} S$ values of oceanic sulfates in the late Paleoproterozoic (18\%o-25\%o [99]), we infer that sulfur sources of sulfides in the laminated ores are mixtures of seawater sulfates and magmatic fluids.

\subsubsection{Vein-Type Ores}

As a $\mathrm{Cu}$-affinity element, Os shares similar geochemical behavior with $\mathrm{Cu}$ during magmatic evolution and ore-forming fluid migration. Consequently, Os can act as a tracer for the metal provenance, using the distinctive ${ }^{187} \mathrm{Os} /{ }^{188} \mathrm{Os}$ ratios and $\gamma_{\mathrm{Os}}$ values of the crust and mantle as effective discriminants of different sources.

The vein-type ores have an initial ${ }^{187} \mathrm{Os} /{ }^{188} \mathrm{Os}$ value of $2.8 \pm 1.2$ (Figure $7 \mathrm{a}$ ). The large uncertainty is due to the measurement error caused by low levels of common Os [100]. Both it and the $\gamma_{\mathrm{O}}$ value (+2202) are only slightly smaller than the mean values of continental crust $(3.63$ and +2758 , respectively, [101]), which implies that the ore-forming materials mainly came from the continental crust [102-104]. With the Cu concentration of the Hekou Group being several times higher than its Clark Value [105] and the existence of older laminated ores (Figure 4d), the indications are that the copper of the veined ores was likely derived from the Hekou Group. In addition, the gabbro swarms, spatially and temporally associated with the deposit, originated from enriched mantle (EM I) [106], which has a ${ }^{187} \mathrm{Os} /{ }^{188} \mathrm{Os}$ value of 0.152 and a $\gamma_{\mathrm{Os}}$ value of +19.7 [107], may have contributed a portion of the metals to the vein-type mineralization.

Most $\delta^{34} S$ values of sulfides from the vein-type ores are in the range of $0 \%$ o to $2.2 \%$ (Figure 9 ), suggesting magmatic-sourced sulfur [108-110]. The marked negative $\delta^{34} \mathrm{~S}$ values (from $-10.3 \%$ o to $-3.6 \%$ o) of some veined sulfides largely correspond to the data from the Manxman prospect $(-3.6 \%$ o to $-6.5 \%$ o $)$ and from the Tangdan deposit ( $-5.2 \%$ o to $-14.7 \%$ o), given in Bastrakov et al. [95] and Huang et al. [97], respectively. Bastrakov et al. [95] suggested that such negative values resulted from involvement of sulfur bearing fluids with negative isotopic values. Huang et al. [97] also suggested that a reduced source, such as carbonaceous slate, provided the sulfur source. In view of the fact that carbonaceous slates often act as the floors of orebodies, the enrichment of light sulfur for these ores can be ascribed to the interaction between ore-forming fluids and organic matter. Thus, the sulfur of sources of the sulfides in the vein-type ores are mixtures of magmatic sulfur and biogenic sulfur.

\subsection{Implications for Regional Metallogeny}

Our new geochronological data show that the Hongnipo deposit has formed by two mineralization events at $\sim 1.6$ and $0.8 \mathrm{Ga}$. By contrast, previous data of the Luodang deposit from the same ore field recorded four hydrothermal events, including three main mineralization events at $\sim 1.67, \sim 1.3$ and $\sim 1.1 \mathrm{Ga}$ and a local hydrothermal overprint events at $\sim 0.82 \mathrm{Ga}$ (Figure 10). Although the early mineralization event age $(\sim 1.6 \mathrm{Ga})$ in the Hongnipo deposit is slightly younger than that $(1.67 \mathrm{Ga})$ in the Luodang deposit, they are indistinguishable from the zircon $\mathrm{U}-\mathrm{Pb}$ ages of their respective host rocks ( 1.6-1.7 Ga [5-10]). This geochronological evidence, together with the rifting setting [6,7,51,59], mixed sulfur sources of seawater sulfates and magmas and the typical ore structures, indicates that they were likely to have formed through a volcanic-exhalative-sedimentary process. The early stage mineralization 
is a VMS-type mineralization in the Lala ore field. The late main mineralization event age $(\sim 0.8 \mathrm{Ga})$ in the Hongnipo deposit is much younger than the subsequent main mineralizaion ages $(\sim 1.3$ and $~ 1.1-1.0 \mathrm{Ga})$ in the Luodang deposit. Neoproterozoic magmatism (ages: 850-796 Ma [53,64,65,67,111,112]) and/or metamorphism (ages: $\sim 850 \mathrm{Ma}[15,113,114]$ ) is likely responsible for the youngest main mineralization event at Hongnipo.

\begin{tabular}{|c|c|c|c|}
\hline \multirow{2}{*}{ 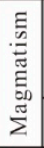 } & $\begin{array}{l}\text { Intrusive } \\
\text { rocks }\end{array}$ & $\begin{array}{c}\text { Zircon } \mathrm{U}-\mathrm{Pb} \\
\text { Whole-rock Sm-Nd }\end{array}$ & $\begin{array}{l}\boldsymbol{4} \uparrow \\
\ldots\end{array}$ \\
\hline & Volcanics & Zircon U-Pb & 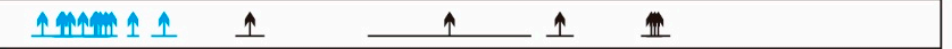 \\
\hline \multicolumn{2}{|r|}{ Metamorphism } & $\begin{array}{c}\text { Muscovite Ar-Ar } \\
\text { Biotite Ar-Ar } \\
\text { Zircon U-Pb }\end{array}$ & 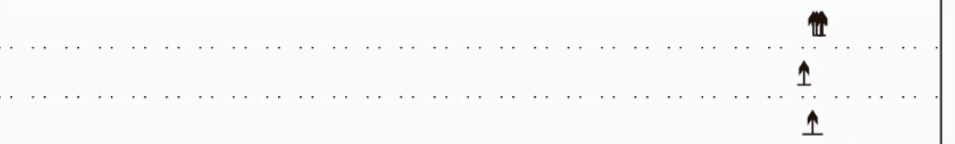 \\
\hline \multirow{5}{*}{ 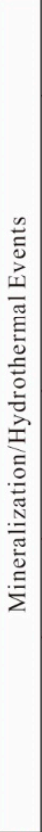 } & Hongnipo & $\begin{array}{l}\text { Chalcopyrite Re-Os } \\
\text { Pyrite } \mathrm{Rb}-\mathrm{Sr}\end{array}$ & 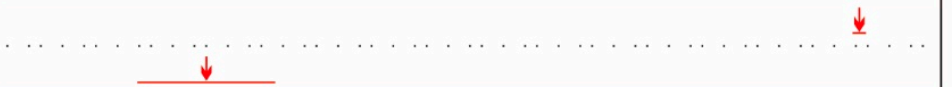 \\
\hline & Luodang & $\begin{array}{l}\text { Pyrite and chalcopyrite } \\
\text { in situ Pb-Pb } \\
\text { Molybdenite Re-Os } \\
\text { Chalcopyrite Re-Os } \\
\text { Allanite } \mathrm{U}-\mathrm{Pb} \\
\text { Biotite Ar-Ar } \\
\text { Sulfide separates } \mathrm{Pb}-\mathrm{Pb}\end{array}$ & 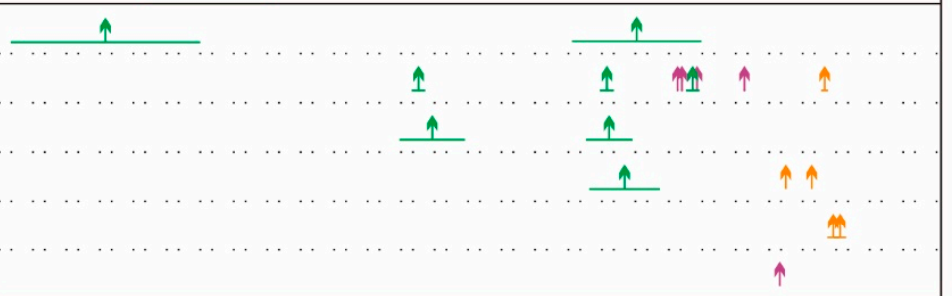 \\
\hline & Yinachang & $\begin{array}{l}\text { Monazite } \mathrm{U}-\mathrm{Pb} \\
\text { Chalcopyrite Re-Os } \\
\text { Molybdenite Re-Os }\end{array}$ & 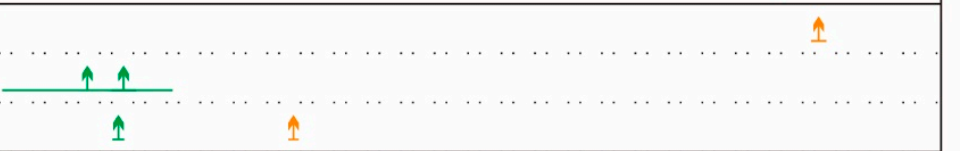 \\
\hline & Etouchang & $\begin{array}{l}\text { Single-grain pyrite } \mathrm{Rb}-\mathrm{Sr} \\
\text { Pyrite Re-Os }\end{array}$ & $\ldots \ldots \ldots \ldots \ldots$ \\
\hline & Dahongshan & $\begin{array}{l}\text { Chalcopyrite Re-Os } \\
\text { Pyrite Re-Os } \\
\text { Molybdenite Re-Os } \\
\quad \text { Zircon U-Pb }\end{array}$ & 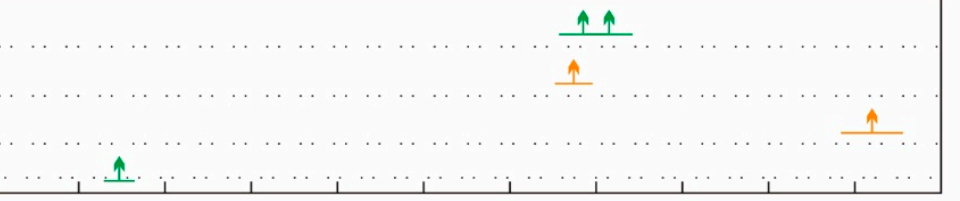 \\
\hline & & $\begin{array}{l}\text { es } \downarrow \text { This study } 1 \text { Hos } \\
\text { I Mineralization eve } \\
\text { per descriptions }\end{array}$ & 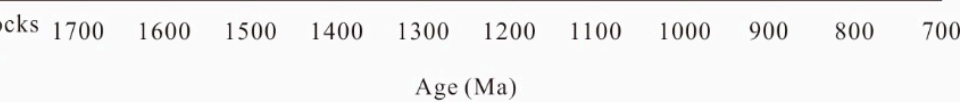 \\
\hline
\end{tabular}

Figure 10. Summary of geochronological data, showing the timing of magmatism, metamorphism, hydrothermal events, and mineralization for the Kangdian copper belt. Data sources as referenced in text and includes the data of present study.

Many other deposits (e.g., Yinachang, Etouchang and Dahongshan) in the Kangdian copper belt are hosted in comparable volcano-sedimentary sequences and share similar mineralization styles, indicating that they might have had a similar metallogenic history.

A number of geochronological data of other representative deposits in the Kangdian copper belt have been published so far. Ye et al. [115] and Hou et al. [116] reported chalcopyrite Re-Os isochron ages of $1690 \pm 99 \mathrm{Ma}$ and $1648 \pm 14 \mathrm{Ma}$, respectively, for the formation timing of the Yinachang deposit. Zhao et al. [1] obtained two groups of Re-Os molybdenite ages, with average ages of $1654 \pm 7 \mathrm{Ma}$ and $1451 \pm 6 \mathrm{Ma}$. They suggested that the Yinachang deposit was formed at $1654 \pm 7 \mathrm{Ma}$, and overprinted by a less important and local hydrothermal event. Li and Zhou [117] reported a monazite U-Pb age of $842 \pm 9 \mathrm{Ma}$ and interpreted it as the timing of a post-ore hydrothermal event. Zhao et al. [1] also reported a chalcopyrite $\mathrm{Re}-\mathrm{Os}$ isochron age and a pyrite $\mathrm{Rb}-\mathrm{Sr}$ isochron age of $1487 \pm 110 \mathrm{Ma}$ and $1453 \pm 28 \mathrm{Ma}$, respectively. They suggested that these ages likely recorded the timing of a secondary hydrothermal event. A zircon U-Pb age of $1653 \pm 18$ Ma for hydrothermal zircons from stockwork chalcopyrite-magnetite ore was proposed to represent the timing of major mineralization that formed 
the Dahongshan deposit [58]. Zhao et al. [58] also reported pyrite and molybdenite Re-Os ages of $1026 \pm 22 \mathrm{Ma}$ and $780 \pm 36 \mathrm{Ma}$, and argued that they recorded the timing of post-ore hydrothermal overprint or remobilization. Song [18] and Jin et al. [57] reported two Re-Os chalcopyrite ages of $1083 \pm 45 \mathrm{Ma}$ and $1115 \pm 28 \mathrm{Ma}$, respectively, to constrain the timing of the main mineralization event. Compiling all the geochronological data together (Figure 10), the Kangdian copper belt has experienced several mineralization and hydrothermal events as follows: (1) the earliest main mineralization at 1.6-1.67 Ga, which is nearly synchronous with host rock (ages: 1.6-1.7 Ga [6-8,10,39,51,59,118]); (2) a local hydrothermal overprint at $\sim 1.45 \mathrm{Ga}$, which is related to early Mesoproterozoic magmatism (age: $\sim 1.5 \mathrm{Ga}[54,62,119]$ ); (3) a second major mineralization at $\sim 1.3 \mathrm{Ga}$, which may have been caused by volcanism (age: $1270 \pm 95 \mathrm{Ma}$ [20]); (4) the third major mineralization at $\sim 1.1-1.0 \mathrm{Ga}$, which is closely associated with late Mesoproterozoic magmatism (ages: 1142-1208 Ma [19-21,52,120]); (5) the fourth major mineralization at $\sim 0.8 \mathrm{Ga}$, which is a newly identified main mineralization event in the Kangdian copper belt, and likely related to the Neoproterozoic magmatism (ages: $~ 850 \mathrm{Ma}[15,113,114]$ ) and/or metamorphism (ages: $850 \mathrm{Ma}[15,113,114])$.

\section{Conclusions}

The Hongnipo copper deposit, a newly discovered large deposit, is roughly strata bound, with orebodies consisting of laminated, vein-type and superimposed ores. Two mineralization events have been identified in this study. Pyrite separates from laminated ores yield a Rb-Sr isochron age of $1552 \pm 80 \mathrm{Ma}$, representing an early mineralization event. In contrast, chalcopyrite separates from vein-type ores yield a much younger Re-Os isochron age of 794.8 \pm 7.9 Ma, reflecting the main mineralization event.

The highly radiogenic initial ${ }^{87} \mathrm{Sr} /{ }^{86} \mathrm{Sr}$ and ${ }^{187} \mathrm{Os} /{ }^{188} \mathrm{Os}$ values of pyrites from the laminated ores and chalcopyrites from veined ores, respectively, suggest significant contributions of crustal materials. Sulfur isotopic compositions of the laminated and vein-type ores are quite different. The majority of the sulfides from the laminated ores have much higher $\delta^{34} S$ values (5\% to $12 \%$ ) than those of the vein-type ores (-11\% to $4 \%$ o). Sulfur of the laminated ores was likely sourced from seawater sulfates and magmatic fluids, while sulfur of the vein-type ores probably came predominantly from magmatic sulfur with minor biogenic sulfur.

The early laminated mineralization identified in the Hongnipo deposit is likely a VMS-type mineralization, and is widespread in the Kangdian copper belt. The late hydrothermal mineralization is likely related to extensive Neoproterozoic magmatism and/or metamorphic events and is responsible for the formation of economic vein-type mineralization. At present, there is no evidence of this later mineralization event at any of the other deposits of the Kangdian copper belt.

Author Contributions: Conceptualization, L.L., R.C., Z.P. and H.C.; field work and experiment, L.L., H.C. and H.J.; writing-original draft preparation, L.L.; writing—review and editing, R.C., Z.P., H.C., J.X. and H.J. All authors have read and agreed to the published version of the manuscript.

Funding: This study was financially supported by National Key Research and Development Program of China (Grant 2017YFC0601506) and Geological Survey Project of China Geological Survey (Grant DD20160052, DD20190570).

Acknowledgments: We are grateful to the Editor and three anonymous reviewers from this journal for their constructive and helpful comments and suggestions. We thank Kunfeng Qiu and Wenjun Hu for their valuable comments and constructive suggestions. We also thank Lingming Gong, Hongtao Shen and Yuanwen Deng for their help during field work. We would like to thank Kuidong Zhao, Mu Liu and Chao Li for their assistance with the lab work.

Conflicts of Interest: The authors declare no conflict of interest.

\section{References}

1. Zhao, X.F.; Zhou, M.F.; Li, J.W.; Selby, D.; Li, X.H.; Qi, L. Sulfide Re-Os and Rb-Sr isotope dating of the Kangdian IOCG metallogenic province, Southwest China: Implications for regional metallogenesis. Econ. Geol. 2013, 108, 1489-1498. [CrossRef] 
2. Chen, W.T.; Zhou, M.F. Ages and compositions of primary and secondary allanite from the Lala Fe-Cu deposit, SW China: Implications for multiple episodes of hydrothermal events. Contrib. Mineral. Petrol. 2014, 168, 1043. [CrossRef]

3. Li, X.C.; Zhao, X.F.; Zhou, M.F.; Chen, W.T.; Chu, Z.Y. Fluid Inclusion and Isotopic Constraints on the Origin of the Paleoproterozoic Yinachang Fe-Cu-(REE) Deposit, Southwest China. Econ. Geol. 2015, 110, 1339-1369. [CrossRef]

4. Su, Z.K.; Zhao, X.F.; Li, X.C.; Zhou, M.F. Using elemental and boron isotopic compositions of tourmaline to trace fluid evolutions of IOCG systems: The worldclass Dahongshan Fe-Cu deposit in SW China. Chem. Geol. 2016, 441, 265-279. [CrossRef]

5. He, D.F. Petrological and Geochemical Characteristics of the Lala Copper Deposit in Sichuan Province. Ph.D. Thesis, Institute of Geochemistry, Chinese Academy of Sciences, Guiyang, China, 2009.

6. Zhou, J.Y.; Mao, J.W.; Liu, F.Y.; Tan, H.Q.; Shen, B.; Zhu, Z.M.; Chen, J.B.; Luo, L.P.; Zhou, X.; Wang, Y. SHRIMP $\mathrm{U}-\mathrm{Pb}$ zircon chronology and geochemistry of albitite from the Hekou Group in the western Yangtze Block. J. Mineral. Petrol. 2011, 31, 66-73. (In Chinese with English abstract).

7. Chen, W.T.; Zhou, M.F.; Zhao, X.F. Late Paleoproterozoic sedimentary and mafic rocks in the Hekou area, SW China: Implication for the reconstruction of the Yangtze Block in Columbia. Precambrian Res. 2013, 231, 61-77. [CrossRef]

8. Zhu, Z.M.; Hou, K.J.; Zhu, K.Y.; Tan, H.Q. Geochronology and geochemistry of the Hekou Group in Sichuan Province, SW China. Geochem. J. 2013, 47, 51-64. [CrossRef]

9. Yu, W.J.; Luo, Z.H.; Liu, Y.S.; Sun, J.Y.; Li, Z.; Wang, Z.; Tang, Z.X. Petrogenesis of the Lala iron-copper deposit: Evidence by cryptoexplosive breccia CSD data and their zircon U-Pb data. Acta Geol. Sin. 2017, 33, 925-941.

10. Zhu, Z.M.; Tan, H.Q.; Liu, Y.D. Late Paleoproterozoic Hekou Group in Sichuan, Southwest China: Geochronological framework and tectonic implications. Int. Geol. Rev. 2018, 60, 305-318. [CrossRef]

11. Chen, G.W.; Cheng, D.R.; Yu, X.W. The typomorphic feature of pyrite in the copper deposit of Lala, Sichuan Province. J. Mineral. Petrol. 1992, 12, 85-91. (In Chinese with English abstract).

12. Chen, G.W.; Xia, B. Study on the genesis of Lala copper deposit, Sichuan Province. Bull. Mineral. Petrol. Geochem. 2001, 20, 42-44. (In Chinese with English abstract).

13. Li, Z.Q.; Wang, J.Z.; Liu, J.J.; Li, C.Y.; Du, A.D.; Liu, Y.P.; Ye, L. Re-Os dating of molybdenite from Lala Fe-Oxide-Cu-Au-Mo-REE deposit, Southwest China: Implications for ore genesis. Contrib. Geol. Mineral Resour. Res. 2003, 18, 39-42. (In Chinese with English abstract).

14. Sun, Y.; Shu, X.L.; Xiao, Y.F. Isotopic geochemistry of the Lala copper deposit, Sichuan Province, China and its metallogenenic significance. Geochimica 2006, 35, 553-559. (In Chinese with English abstract).

15. Greentree, M.R. Tectonostratigraphic Analysis of the Proterozoic Kangdian Iron Oxide-Copper Province South-west China. Unpublished. Ph.D. Thesis, University of Western Australia, Perth, Australia, 2007.

16. Chen, W.T.; Zhou, M.F. Paragenesis, stable isotopes, and molybdenite Re-Os isotope age of the Lala iron-copper deposit, Southwest China. Econ. Geol. 2012, 107, 459-480. [CrossRef]

17. Zhu, Z.M.; Sun, Y.L. Direct Re-Os dating of chalcopyrite from the Lala IOCG deposit in the Kangdian Copper Belt, China. Econ. Geol. 2013, 108, 871-882.

18. Song, H. Precambrian Copper-Iron-Gold-Uranium Polymetallic Deposits and Their Regional Metallogeny in Southwestern Margin of Yangtze Block. Ph.D. Thesis, Chengdu University of Technology, Chengdu, China, 2014.

19. Geng, Y.S.; Yang, C.H.; Du, L.L.; Wang, X.S.; Ren, L.D.; Zhou, X.W. Chronology and tectonic environment of the Tianbaoshan Formation: New evidence from zircon SHRIMP U-Pb age and geochemistry. Geol. Rev. 2007, 53, 556-563. (In Chinese with English abstract).

20. Yin, F.G.; Sun, Z.M.; Zhang, Z. Mesoproterozoic stratigraphic structure framework in Huili-Dongchuan area. Geol. Rev. 2011, 57, 770-778. (In Chinese with English abstract).

21. Wang, Z.Z.; Zhou, B.G.; Guo, Y.; Yang, B.; Liao, Z.W.; Wang, S.W. Geochemistry and zircon U-Pb dating of Tangtang granite in the western margin of the Yangtze Platform. Acta Petrol. Minrel. 2012, 31, 652-662, (In Chinese with English abstract).

22. Zhou, M.F.; Zhao, X.F.; Chen, W.T.; Li, X.C.; Wang, W.; Yan, D.P.; Qiu, H.N. Proterozoic Fe-Cu metallogeny and supercontinental cycles of the southwestern Yangtze Block, southern China and northern Vietnam. Earth Sci. Rev. 2014, 139, 59-82. [CrossRef] 
23. Zhu, Z.M.; Tan, H.Q.; Liu, Y.D.; Li, C. Multiple episodes of mineralization revealed by Re-Os molybdenite geochronology in the Lala Fe-Cu deposit, SW China. Miner. Depos. 2018, 53, 311-322. [CrossRef]

24. Chen, W.T.; Zhou, M.F.; Li, X.F.; Gao, J.F.; Bao, Z.A.; Yuan, H.L. In situ Pb-Pb isotopic dating of sulfides from hydrothermal deposits: A case study of the Lala Fe-Cu deposit, SW China. Miner. Depos. 2019, 54, 671-682. [CrossRef]

25. Zhu, Z.M. Lala Iron Oxide Copper Gold Deposit: Metallogenic Epoch and Metal Sources. Ph.D. Thesis, Chengdu University of Technology, Chengdu, China, 2011.

26. Gong, L.M.; Shen, H.M.; Huang, S.Z.; Wang, Y.; Zou, F.; Xiao, Y.C.; Li, Y.; Zhang, X.Y.; Zhang, C.; Li, G.Q.; et al. The Report of Copper Exploration of Hongnipo Ore District, Huili County, Sichuan Province; Geological Team 403 of Sichuan Geological and Mineral Exploration and Development Bureau: Leshan, China, 2016.

27. Zhu, Z.M. Metallogenic background and deposit types of Hongnipo copper deposit in Huili, Sichuan. Miner. Depot 2012, 31, 413-414.

28. Hu, X.P.; Zhang, J.L.; Li, S.Y.; Yang, K.J.; Hu, H.B. Geological features and their prospecting significance of the Hongnipo Cu deposit. Acta Geol. Sichuan 2016, 36, 264-268. (In Chinese with English abstract).

29. Zhang, W.P.; Yu, C.; Li, F.; Zeng, Q.T.; Zhang, D.B.; Zhang, Z.F.; Lv, J.N. Geological characteristics and ore-controlling factors of Hongnipo copper deposit in Huili of Sichuan. Nonferrous Met. Eng. 2016, 6, 80-84. (In Chinese with English abstract).

30. Wang, Y.P. Study on the Geochemical Characteristics of Hongnipo Mine Section of Lala Copper Deposit in Huili, Sichuan Province. Master's Thesis, Chengdu University of Technology, Chengdu, China, 2017.

31. Qiu, K.F.; Yu, H.C.; Wu, M.Q.; Geng, J.Z.; Ge, X.K.; Gou, Z.Y.; Taylor, R.D. Discrete Zr and REE mineralization of the Baerzhe rare-metal deposit, China. Am. Mineral. 2019, 104, 1487-1502. [CrossRef]

32. Qiu, K.F.; Yu, H.C.; Deng, J.; Mclntire, D.; Gou, Z.Y.; Geng, J.Z.; Chang, Z.S.; Zhu, R.; Li, K.N.; Goldfarb, R. The giant Zaozigou Au-Sb deposit in West Qinling, China: Magmatic- or metamorphic-hydrothermal origin? Miner. Depos. 2020, 55, 345-362. [CrossRef]

33. Li, Z.X.; Zhang, L.H.; Powell, C.M. South China in Rodinia: Part of the missing link between Australia-East Antarctica and Laurentia? Geology 1995, 23, 407-410. [CrossRef]

34. Xu, X.S.; O’Reilly, S.Y.; Griffin, W.L.; Wang, X.L.; Pearson, N.J.; He, Z.Y. The crust of Cathaysia: Age, assembly and reworking of two terranes. Precambrian Res. 2007, 158, 51-78. [CrossRef]

35. Li, Z.X.; Li, X.H.; Zhou, H.; Kinny, P.D. Grenville-aged continental collision in South China: New SHRIMP $\mathrm{U}-\mathrm{Pb}$ zircon results and implications for the configuration of Rodinia. Geology 2002, 30, 163-166. [CrossRef]

36. Qiu, Y.M.; Gao, S.; McNaughton, N.J.; Groves, D.I.; Ling, W. First evidence of $>3.2$ Ga continental crust in the Yangtze craton of South China and its implications for Archean crustal evolution and Phanerozoic tectonics. Geology 2000, 28, 11-14. [CrossRef]

37. Zheng, J.P.; Griffin, W.L.; O’Reilly, S.Y.; Zhang, M.; Pearson, N.J.; Pan, Y.M. Widespread Archean basement beneath the Yangtze Craton. Geology 2006, 34, 417-420. [CrossRef]

38. Sun, W.H.; Zhou, M.F.; Gao, J.F.; Yang, Y.H.; Zhao, X.F.; Zhao, J.H. Detrital zircon U-Pb geochronological and Lu-Hf isotopic constraints on the Precambrian magmatic and crustal evolution of the western Yangtze Block, SW China. Precambrian Res. 2009, 172, 99-126. [CrossRef]

39. Zhao, X.F.; Zhou, M.F.; Li, J.W.; Sun, M.; Gao, J.F.; Sun, W.H.; Yang, J.H. Late Paleoproterozoic to early Mesoproterozoic Dongchuan Group in Yunnan, SW China: Implications for tectonic evolution of the Yangtze Block. Precambrian Res. 2010, 182, 57-69. [CrossRef]

40. Wang, L.J.; Griffin, W.L.; Yu, J.H.; O’Reilly, S.Y. Precambrian crustal evolution of the Yangtze Block tracked by detrital zircons from Neoproterozoic sedimentary rocks. Precambrian Res. 2010, 177, 131-144. [CrossRef]

41. Wang, L.J.; Yu, J.H.; Griffin, W.L.; O’Reilly, S.Y. Early crustal evolution in the western Yangtze Block: Evidence from $\mathrm{U}-\mathrm{Pb}$ and $\mathrm{Lu}-\mathrm{Hf}$ isotopes on detrital zircons from sedimentary rocks. Precambrian Res. 2012, 222-223, 368-385. [CrossRef]

42. Zhang, S.B.; Zheng, Y.F.; Wu, Y.B.; Zhao, Z.F.; Gao, S.; Wu, F.Y. Zircon isotope evidence for $\geq 3.5$ Ga continental crust in the Yangtze craton of China. Precambrian Res. 2006, 146, 16-34. [CrossRef]

43. Sun, M.; Chen, N.; Zhao, G.; Wilde, S.A.; Ye, K.; Guo, J.; Chen, Y.; Yuan, C. U-Pb zircon and Sm-Nd isotopic study of the Huangtuling granulite, Dabie-Sulu belt, China: Implication for the Paleoproterozoic tectonic history of the Yangtze Craton. Am. J. Sci. 2008, 308, 469-483. [CrossRef] 
44. Wu, Y.B.; Zheng, Y.F.; Gao, S.; Jiao, W.F.; Liu, Y.S. Zircon U-Pb age and trace element evidence for Paleoproterozoic granulite-facies metamorphism and Archean crustal rocks in the Dabie Orogen. Lithos 2008, 101, 308-322. [CrossRef]

45. Xiong, Q.; Zheng, J.P.; Yu, C.M.; Su, Y.P.; Tang, H.Y.; Zhang, Z.H. Zircon U-Pb age and Hf isotope of Quanyishang A-type granite in Yichang: Signification for the Yangtze continental cratonization in Paleoproterozoic. Chin. Sci. Bull. 2009, 54, 436-446. [CrossRef]

46. Peng, M.; Wu, Y.B.; Wang, J.; Jiao, W.F.; Liu, X.C.; Yang, S.H. Paleoproterozoic mafic dyke from Kongling terrain in the Yangtze Craton and its implication. Chin. Sci. Bull. 2009, 54, 1098-1104. [CrossRef]

47. Peng, M.; Wu, Y.B.; Gao, S.; Zhang, H.F.; Wang, J.; Liu, X.C.; Gong, H.J.; Zhou, L.; Hu, Z.C.; Liu, Y.S.; et al. Geochemistry, zircon $\mathrm{U}-\mathrm{Pb}$ age and $\mathrm{Hf}$ isotope compositions of Paleoproterozoic aluminous A-type granites from the Kongling terrain, Yangtze Block: Constraints on petrogenesis and geologic implications. Gondwana Res. 2012, 22, 140-151. [CrossRef]

48. Zhao, G.C.; Cawood, P.A. Tectonothermal evolution of the Mayuan assemblage in the Cathaysia block: New evidence for Neoproterozoic collional-related assembly of the South China Craton. Am. J. Sci. 1999, 299, 309-339. [CrossRef]

49. Li, Z.X.; Bogdanova, S.V.; Collins, A.S.; Davidson, A.; De Waele, B.; Ernst, R.E.; Fitzsimons, I.C.W.; Fuck, R.A.; Gladkochub, D.P.; Jacobs, J.; et al. Assembly, configuration, and break-up history of Rodinia: A synthesis. Precambrian Res. 2008, 160, 179-210. [CrossRef]

50. Yan, D.P.; Zhou, M.F.; Song, H.L.; Wang, X.W.; Malpas, J. Origin and tectonic significance of a Mesozoic multi-layer over-thrust within the Yangtze Block (South China). Tectonophysics 2003, 361, 239-254. [CrossRef]

51. Greentree, M.R.; Li, Z.X. The oldest known rocks in south-western China: SHRIMP U-Pb magmatic crystallisation age and detrital provenance analysis of the Paleoproterozoic Dahongshan Group. J. Asian Earth Sci. 2008, 33, 289-302. [CrossRef]

52. Greentree, M.R.; Li, Z.X.; Li, X.H.; Wu, H.C. Late Mesoproterozoic to earliest Neoproterozoic basin record of the Sibao orogenesis in western South China and relationship to the assembly of Rodinia. Precambrian Res. 2006, 151, 79-100. [CrossRef]

53. Zhou, M.F.; Ma, Y.; Yan, D.P.; Xia, X.; Zhao, J.H.; Sun, M. The Yanbian Terrane (Southern Sichuan Province, SW China): A Neoproterozoic arc assemblage in the western margin of the Yangtze Block. Precambrian Res. 2006, 144, 19-38. [CrossRef]

54. Sun, Z.M.; Yin, F.G.; Guan, J.L.; Liu, J.H.; Li, J.M.; Geng, Y.R.; Wang, L.Q. SHRIMP U-Pb dating and its stratigraphic significance of tuff zircons from Heishan formation of Kunyang Group, Dongchuan area, Yunnan Province, China. Geol. Bull. China 2009, 28, 896-900. (In Chinese with English abstract).

55. Li, F.H.; Tan, J.M.; Shen, Y.L.; Yu, F.X.; Zhou, G.F.; Pan, X.N.; Li, X.Z. The Presinian in the Kangdian Area; Chongqing Publishing House: Chongqing, China, 1998; (In Chinese with English abstract).

56. Chen, Z.L.; Chen, S.Y. On the Tectonic Evolution of the West Margin of the Yangzi Block; Chongqing Publishing House: Chongqing, China, 1987; (In Chinese with English abstract).

57. Jin, T.F.; Li, Y.G.; Fei, C.G.; Zhou, H.; Sha, X.B.; Feng, Y.C.; Wu, K. Re-Os isotopic dating of chalcopyrite in quartz vein from Dahongshan IOCG Deposit in Kangdian Copper Metallogenic Belt and its significance. Acta Mineral. Sin. 2017, 37, 417-426. (In Chinese with English abstract).

58. Zhao, X.F.; Zhou, M.F.; Su, Z.K.; Li, X.F.; Chen, W.T.; Li, J.W. Geology, geochronology, and geochemistry of the Dahongshan Fe-Cu-(Au-Ag) deposit, Southwest China: Implications for the formation of iron oxide copper-gold deposits in intracratonic rift settings. Econ. Geol. 2017, 112, 603-628. [CrossRef]

59. Zhao, X.F.; Zhou, M.F. Fe-Cu deposits in the Kangdian region, SW China: A Proterozoic IOCG (iron-oxide-copper-gold) metallogenic province. Miner. Depos. 2011, 46, 731-747. [CrossRef]

60. Wang, D.B.; Yin, F.G.; Sun, Z.M.; Wang, L.Q.; Wang, B.D.; Liao, S.Y.; Tan, Y.; Ren, G.M. Zircon U-Pb age and Hf isotope of Paleoproterozoic mafic intrusion on the western margin of the Yangtze Block and their implications. Geol. Bull. China 2013, 32, 617-630. (In Chinese with English abstract).

61. Wang, Z.Z.; Guo, Y.; Yang, B.; Wang, S.W.; Sun, X.M.; Hou, L.; Zhou, B.G.; Liao, Z.W. Discovery of the 1.73 Ga Haizi anorogenic type granite in the western margin of Yangtze Craton, and its geological significance. Acta Geol. Sin. 2013, 87, 931-942. (In Chinese with English abstract).

62. Fan, H.P.; Zhu, W.G.; Li, Z.X.; Zhong, H.; Bai, Z.J.; He, D.F.; Chen, C.J.; Cao, C.Y. Ca. 1.5 Ga mafic magmatism in South China during the break-up of the supercontinent Nuna/Columbia: The Zhuqing Fe-Ti-V oxide ore-bearing mafic intrusions in western Yangtze Block. Lithos 2013, 168-169, 85-98. [CrossRef] 
63. Zhu, W.G.; Bai, Z.J.; Zhong, H.; Ye, X.T.; Fan, H.P. The origin of the c. 1.7 Ga gabbroic intrusion in the Hekou area, SW China: Constraints from SIMS U-Pb zircon geochronology and elemental and Nd isotopic geochemistry. Geol. Mag. 2017, 154, 286-304. [CrossRef]

64. Zhou, M.F.; Yan, D.P.; Kennedy, A.K.; Li, Y.Q.; Ding, J. SHRIMP U-Pb zircon geochronological and geochemical evidence for Neoproterozoic arc-magmatism along the western margin of the Yangtze Block, South China. Earth Planet. Sci. Lett. 2002, 196, 51-67. [CrossRef]

65. Li, X.H.; Li, Z.X.; Ge, W.; Zhou, H.; Li, W.; Liu, Y.; Wingate, M.T.D. Neoproterozoic granitoids in South China: Crustal melting above a mantle plume at ca. $825 \mathrm{Ma}$ ? Precambrian Res. 2003, 122, 45-83. [CrossRef]

66. Zhou, M.F.; Kennedy, A.K.; Sun, M.; Malpas, J.; Lesher, C.M. Neoproterozoic arc-related mafic intrusions along the northern margin of South China: Implications for the accretion of Rodinia. J. Geol. 2002, 110, 611-618. [CrossRef]

67. Zhao, X.F.; Zhou, M.F.; Li, J.W.; Wu, F.Y. Association of Neoproterozoic A-and I-type granites in South China: Implications for generation of A-type granites in a subduction-related environment. Chem. Geol. 2008, 257, 1-15. [CrossRef]

68. Li, Z.X.; Li, X.H.; Kinny, P.D.; Wang, J.; Zhang, S.; Zhou, H. Geochronology of Neoproterozoic syn-rift magmatism in the Yangtze Craton, South China and correlations with other continents: Evidence for a mantle superplume that broke up Rodinia. Precambrian Res. 2003, 122, 85-109. [CrossRef]

69. Li, H.B.; Zhang, Z.C.; Santosh, M.; Li, Y.S.; Han, L.; Zhu, J.; Pan, R.H. Geochronological, geochemical and Sr-Nd isotopic fingerprinting of Neoproterozoic mafic dykes in the western margin of the Yangtze Block, SW China: Impications for Rodinia supercontinent breakup. Precambrian Res. 2019, 331, 105371. [CrossRef]

70. Ren, J.S.; Wang, Z.X.; Chen, B.W.; Jiang, C.F.; Niu, B.G.; Li, J.R.; Xie, G.L.; He, Z.J.; Liu, Z.G. The Tectonics of China from a Global View: A Guide to the Tectonic Map of China and Adjacent Regions; Geological Publishing House: Beijing, China, 1999. (In Chinese)

71. EJ/T 692-1992. Determination of Rb-Sr Isochronous Age of Rocks and Minerals; China National Nuclear Corporation: Beijing, China, 1992. (In Chinese)

72. Ludwig, K.R. Isoplot/Ex, Version 3: A Geochronological Toolkit for Microsoft Excel: Geochronology Center Berkeley; Geochronology Center Berkeley: Berkeley, CA, USA, 2003.

73. Du, A.D.; Zhao, D.M.; Wang, S.X.; Sun, D.Z.; Liu, D.Y. Precise Re-Os dating for molybdenite by ID-NTIMS with carius tube sample preparation. Rock Miner. Anal. 2001, 20, 247-252. (In Chinese with English abstract).

74. Du, A.D.; Wu, S.Q.; Sun, D.F.; Wang, S.X.; Qu, W.J.; Markey, R.; Stain, H.; Morgan, J.; Malinovskiy, D. Preparation and certification of Re-Os dating reference materials: Molybdenites HLP and JDC. Geostand. Geoanal. Res. 2004, 28, 41-52. [CrossRef]

75. Li, C.; Qu, W.Q.; Zhou, L.M.; Du, A.D. Rapid separation of osmium by direct distillation with Carius tube. Rock Miner. Anal. 2010, 29, 14-16. (In Chinese with English abstract).

76. Li, C.; Yang, X.; Zhao, H.; Zhou, L.M.; Du, A.D.; Li, X.W.; Qu, W.J. High precise isotopic measurements of pg-ng Os by negative ion thermal ionization mass spectrometry. Rock Miner. Anal. 2015, 34, 392-398. (In Chinese with English abstract).

77. Li, C.; Zhou, L.M.; Du, A.D.; Yang, G.; Li, X.W.; Qu, W.J. N-TIMS measurement and calculation method for Re-Os isotopes. Geochimica 2017, 46,1-14. (In Chinese with English abstract). [CrossRef]

78. Nier, A.O. The isotopic constitution of Osmium. Phys. Rev. 1937, 52, 885-892. [CrossRef]

79. Liu, G.Q.; Zhao, K.D.; Jiang, S.Y.; Chen, W. In-situ sulfur isotope and trace element analysis of pyrite form the Xiwang uranium ore deposit in South China: Implication for ore genesis. J. Geochem. Explor. 2018, 195, 49-65. [CrossRef]

80. Chen, G.Y.; Shao, W.; Sun, D.S. Genetic Mineralogy of Gold Deposits in Jiaodong Region with Emphasis on Gold Prospecting; Chongqing Publishing House: Chongqing, China, 1989.

81. Halliday, A.N.; Ohr, M.; Mezger, K.; Chesly, J.T.; Nakai, S.; Dewolf, C.P. Recent development in dating ancient crust fluid flow. Rev. Geophys. 1991, 72, 527-548.

82. Yang, J.H.; Zhou, X.H. Rb-Sr, Sm-Nd, and Pb isotope systematics of pyrite: Implications for the age and genesis of lode gold deposits. Geology 2001, 29, 711-714. [CrossRef]

83. Li, Q.L.; Chen, F.K.; Yang, J.H.; Fan, H.Y. Single grain Rb-Sr dating of the Linglong gold deposit, eastern China. Ore Geol. Rev. 2008, 34, 263-270. [CrossRef]

84. Faure, G.; Mensing, T.M. Isotopes: Principles and Applications; Wiley: Hoboken, NJ, USA, 2005. 
85. Tripathy, G.R.; Singh, S.K. Re-Os depositional age for black shales from the Kaimur Group, Upper Vindhyan, India. Chem. Geol. 2015, 413, 63-72. [CrossRef]

86. Selby, D.; Kelley, K.D.; Hitzman, M.W.; Zieg, J. Re-Os sulfide (bornite, chalcopyrite, and pyrite) systematics of the carbonate-hosted copper deposits at Ruby Creek, Southern Brooks Range, Alaska. Econ. Geol. 2009, 104, 437-444. [CrossRef]

87. Li, C.; Qu, W.J.; Du, A.D.; Zhou, L.M. Study on Re-Os isotope in molybdenite containing common Os. Acta Petrol. Sin. 2012, 28, 702-708. (In Chinese with English abstract).

88. Stein, H.J.; Morgan, J.W.; Schersten, A. Re-Os dating of low-level highly radiogenic (LLHR) sulfides: The Harnas gold deposit, southwest Sweden, Records continental scale tectonic events. Econ. Geol. 2000, 95, 1657-1671. [CrossRef]

89. Jiang, S.Y.; Yang, J.H.; Zhao, K.D.; Yu, J.M. Re-Os isotope tracer and dating methods in ore deposits research. J. Nanjing Univ. Nat. Sci. Ed. 2000, 36, 669-677. (In Chinese with English abstract).

90. Walker, R.J.; Carlson, R.W.; Shirey, S.B.; Boyd, F.R. OS, Sr, Nd, and Pb isotope systematics of southern African peridotite xenoliths: Implications for the chemical evolution of subcontinental mantle. Geochim. Cosmochim. Acta 1989, 53, 1583-1595. [CrossRef]

91. Smoliar, M.I.; Walker, R.J.; Morgan, J.W. Re-Os ages of group IIA, IIIA, IVA, and IVB iron meteorites. Science 1996, 271, 1099-1102. [CrossRef]

92. Chen, W.T.; Zhou, M.F.; Gao, J.F. Constraints of Sr isotopic compositions of apatite and carbonates on the origin of Fe and $\mathrm{Cu}$ mineralizing fluids in the Lala Fe-Cu-(Mo, LREE) deposit, SW China. Ore Geol. Rev. 2014, 61, 96-106. [CrossRef]

93. Zhao, X.F.; Zhou, M.F.; Gao, J.F.; Li, X.C.; Li, J.W. In situ Sr isotope analysis of apatite by LA-MC-ICPMS: Constraints on the evolution of ore fluids of the Yinachang Fe-Cu-REE deposit, Southwest China. Miner. Depos. 2015, 50, 871-884. [CrossRef]

94. Zhao, X.F.; Zhou, M.F.; Hitzman, M.W.; Li, J.W.; Bennett, M.; Meighan, C.; Anderson, E. Late Paleoproterozoic to early Mesoptoterozoic Tangdan sedimentary rock-hosted strata-bound copper deposit, Yunnan Province, Southwest China. Econ. Geol. 2012, 107, 357-375. [CrossRef]

95. Bastrakov, E.N.; Skirrow, R.G.; Davidson, G.J. Fluid Evolution and Origins of Iron Oxide Cu-Au Prospects in the Olympic Dam District, Gawler Craton, South Australia. Econ. Geol. 2007, 102, 1415-1440. [CrossRef]

96. Kuntson, J.; Donnelly, T.H.; Eadington, P.J.; Tonkin, D.C. Hydrothermal alteration of middle Proterozoic basalts, Stuart Shelf, south Australia-A possible source for Cu Mineralizaton. Econ. Geol. 1992, 87, 1054-1077.

97. Huang, X.W.; Zhao, X.F.; Qi, L.; Zhou, M.F. Re-Os and S isotopic constraints on the origins of two mineralization events at the Tangdan sedimentary rock-hosted stratiform Cu deposit, SW China. Chem. Geol. 2013, 347, 9-19. [CrossRef]

98. Liu, Z.C.; Li, F.Y.; Zhong, K.H.; Li, W.; Wen, S.X. Tectonic Evolution and Mineralization of the Western Margin of the Yangtze Platform; China Electronic Science Press: Chengdu, China, 1996.

99. Strauss, H. The sulfur isotopic record of Precambrian sulfates: New data and a critical evaluation of the existing record. Precambrian Res. 1993, 63, 225-246. [CrossRef]

100. Li, C.; Pei, H.X.; Wang, D.Z.; Zhou, L.M.; Zhao, H.; Li, X.W.; Qu, W.J.; Du, A.D. Age and source constraints for Kongxintou copper-molybdenum deposit Shandong from Re-Os isotope in molydbenite and chalcopyrite. Acta Geol. Sin. 2016, 90, 240-249. (In Chinese with English abstract).

101. Palmer, M.R.; Turekian, K.K. ${ }^{187} \mathrm{Os} /{ }^{186}$ Os in marine manganese nodules and the constraints on the crustal geochemistries of rhenium and osmium. Nature 1986, 319, 216-220. [CrossRef]

102. Mathur, R.; Ruiz, J.; Titley, S.; Gibbins, S.; Margotomo, W. Different crustal sources for Au-rich and Au-poor ores of the Grasberg Cu-Au porphyry deposit. Earth Planet. Sci. Lett. 2000, 183, 7-14. [CrossRef]

103. Mathur, R.; Marschik, B.; Ruiz, J.; Munizaga, F.; Leveille, B.A.; Martin, W. Age of mineralization of the Candelaria Fe oxide $\mathrm{Cu}-\mathrm{Au}$ deposit and the origin of the Chilean Iron Belt, based on Re-Os isotopes. Econ. Geol. 2002, 97, 59-71. [CrossRef]

104. Mathur, R.; Titley, S.; Ruiz, J.; Gibbins, S.; Friehauf, K. A Re-Os isotope study of sedimentary rocks and copper-gold ores from the Ertsberg District, West Papua, Indonesia. Ore Geol. Rev. 2005, 26, 207-226. [CrossRef]

105. Sun, Y.; Li, C.D. Mineralization mechanism of Lala copper deposit in Sichuan Province. J. Chengdu Coll. Geol. 1990, 17, 1-9. (In Chinese with English abstract). 
106. Zhou, J.Y.; Zheng, R.C.; Zhu, Z.M.; Chen, J.B.; Shen, B.; Li, X.Y.; Luo, L.P. Geochemistry and Sm-Nd dating of the Gabbro in the Lala copper ore deposit, Sichuan Province, China. Bull. Mineral. Petrol. Geochem. 2009, 28, 111-122. (In Chinese with English abstract).

107. Shirey, S.B.; Walker, R.J. The Re-Os isotope system in cosmochemistry and high-temperature geochemistry. Annu. Rev. Earth Planet. Sci. 1998, 26, 423-500. [CrossRef]

108. Ohmoto, H. Systematics of sulfur and carbon isotopes in hydrothermal ore deposits. Econ. Geol. 1972,67, 551-578. [CrossRef]

109. Qiu, K.F.; Taylor, R.D.; Song, Y.H.; Yu, H.C.; Song, K.R.; Li, N. Geologic and geochemical insights into the formation of the Taiyangshan porphyry copper-molybdenum deposit, Western Qinling Orogenic Belt, China. Gondwana Res. 2016, 35, 40-58. [CrossRef]

110. Qiu, K.F.; Marsh, E.; Yu, H.C.; Pfaff, K.; Gulbransen, C.; Gou, Z.Y.; Li, N. Fluid and metal sources of the Wenquan porphyry molybdenum deposit, Western Qinling, NW China. Ore Geol. Rev. 2017, 86, 459-473. [CrossRef]

111. Li, X.H.; Li, Z.X.; Zhou, H.W.; Liu, Y.; Kinny, P.D. U-Pb zircon geochronology, geochemistry and Nd isotopic tudy of Neoproterozoic bimodal volcanic rocks in the Kangdian Rift of South China: Implications for the initial rifting of Rodinia. Precambrian Res. 2002, 113, 135-154. [CrossRef]

112. Zhu, G.W.; Zhong, H.; Li, X.H.; Deng, H.L.; He, D.F.; Wu, K.W.; Bai, Z.J. SHRIMP zircon U-Pb geochronology, elemental, and $\mathrm{Nd}$ isotopic geochemistry of the Neoproterozoic mafic dykes in the Yanbian area, SW China. Precambrian Res. 2008, 164, 66-85. [CrossRef]

113. Yang, H.; Liu, F.L.; Du, L.L.; Liu, P.H.; Wang, F. Zircon U-Pb dating for metavolcanites in the Laochanghe Formation of the Dahongshan Group in southwestern Yangtze Block, and its geological significance. Acta Petrol. Sin. 2012, 28, 2994-3014. (In Chinese with English abstract).

114. Yang, H.; Liu, F.L.; Liu, P.H.; Wang, F. ${ }^{40} \mathrm{Ar}-{ }^{39} \mathrm{Ar}$ dating for muscovite in garnet muscovite-felsic schists of the Dahongshan Group in southwestern Yangtze Block and itsgeological significance. Acta Petrol. Sin. 2013, 29, 2161-2170. (In Chinese with English abstract).

115. Ye, X.T.; Zhu, W.G.; Zhong, H.; He, D.F.; Ren, T.; Bai, Z.J.; Fan, H.P.; Hu, W.J. Zircon U-Pb and chalcopyrite Re-Os geochronology, REE geochemistry of the Yinachang Fe-Cu-REE deposit in Yunnan Province and its geological significance. Acta Petrol. Sin. 2013, 29, 167-186. (In Chinese with English abstract).

116. Hou, L.; Ding, J.; Deng, J.; Peng, H.J. Geology, geochronology, and geochemistry of the Yinachang Fe-Cu-Au-REE deposit of the Kangdian region of SW China: Evidence for a Paleo-Mesoproterozoic tectono-magmatic event and associated IOCG systems in the western Yangtze Block. J. Asian Earth Sci. 2015, 103, 129-149. [CrossRef]

117. Li, X.C.; Zhou, M.F. Multiple stages of hydrothermal REE remobilization recorded in fluorapatite in the Paleoproterozoic Yinachang Fe-Cu-(REE) deposit, Southwest China. Geochim. Cosmochim. Acta 2015, 166, 53-73. [CrossRef]

118. Wang, D.B.; Sun, Z.M.; Yin, F.G.; Wang, L.Q.; Wang, B.D.; Zhang, W.P. Geochronology of the Hekou Group on the western margin of the Yangtze Block: Evidence from zircon LA-ICP-MS U-Pb dating of volcanic rocks. J. Stratigr. 2012, 36, 630-635. (In Chinese with English abstract).

119. Geng, Y.S.; Liu, Y.Q.; Gao, L.Z.; Pan, N.; Jiang, Z.J. Geochronology of the the Mesoproterozoic Tong'an Formation in southwestern margin of Yangtze Craton: New evidence from zircon LA-ICP-MS U-Pb ages. Acta Geol. Sin. 2012, 86, 1479-1490. (In Chinese with English abstract).

120. Zhang, C.H.; Gao, L.Z.; Wu, Z.J.; Shi, X.Y.; Yan, Q.R.; Li, D.J. SHRIMP U-Pb zircon age of tuff from the Kunyang Group in central Yunnan: Evidence for Grenvillian orogeny in South China. Chin. Sci. Bull. 2007, 52, 306-318. [CrossRef]

(C) 2020 by the authors. Licensee MDPI, Basel, Switzerland. This article is an open access article distributed under the terms and conditions of the Creative Commons Attribution (CC BY) license (http://creativecommons.org/licenses/by/4.0/). 